\title{
Dicalcium Silicate Induced Proinflammatory Responses through TLR2-Mediated NF- $\kappa$ B and JNK Pathways in the Murine RAW 264.7 Macrophage Cell Line
}

\author{
Shixiang Lai, ${ }^{1}$ Liangjiao Chen $\mathbb{D}^{1},{ }^{1}$ Wei Cao, ${ }^{1}$ Shiman Cui, ${ }^{1}$ Xingyang Li, ${ }^{1}$ Wenchao Zhong, ${ }^{1}$ \\ Mingyu Ma, ${ }^{2}$ and Qingbin Zhang ${ }^{1}{ }^{1}$ \\ ${ }^{1}$ Key Laboratory of Oral Medicine, Guangzhou Institute of Oral Disease, Stomatology Hospital of Guangzhou Medical University, \\ Guangzhou 510140, China \\ ${ }^{2}$ The Second Affiliated Hospital of Guangzhou Medical University, Guangzhou 510260, China
}

Correspondence should be addressed to Qingbin Zhang; doctorqingbin@hotmail.com

Received 27 October 2017; Accepted 8 March 2018; Published 2 May 2018

Academic Editor: Yona Keisari

Copyright () 2018 Shixiang Lai et al. This is an open access article distributed under the Creative Commons Attribution License, which permits unrestricted use, distribution, and reproduction in any medium, provided the original work is properly cited.

\begin{abstract}
Proinflammatory responses are important aspects of the immune response to biomaterials, which may cause peri-implantitis and implant shedding. The purpose of this study was to test the cytotoxicity and proinflammatory effects of dicalcium silicate particles on RAW 264.7 macrophages and to investigate the proinflammatory response mechanism induced by $\mathrm{C}_{2} \mathrm{~S}$ and tricalcium phosphate (TCP). $\mathrm{C}_{2} \mathrm{~S}$ and TCP particles were characterized using scanning electron microscopy (SEM), energy spectrum analysis (EDS) and X-ray diffraction (XRD). Cytotoxicity and apoptosis assays with $\mathrm{C}_{2} \mathrm{~S}$ and TCP in the murine RAW 264.7 cell line were tested using the cell counting kit-8 (CCK-8) assay and flow cytometry (FCM). The detection results showed that $\mathrm{C}_{2} \mathrm{~S}$ and TCP particles had no obvious toxicity in RAW 264.7 cells and did not cause obvious apoptosis, although they both caused an oxidative stress response by producing ROS when the concentrations were at $100 \mu \mathrm{g} / \mathrm{mL}$. $\mathrm{C}_{2} \mathrm{~S}$ particles are likely to induce a proinflammatory response by inducing high TLR2, TNF- $\alpha$ mRNA, TNF- $\alpha$ proinflammatory cytokine, p-I $\kappa$ B, and p-JNK1 + JNK2 + JNK3 expression levels. When we added siRNA-TLR2-1, a significant reduction was observed. These findings support the theory that $\mathrm{C}_{2} \mathrm{~S}$ particles induce proinflammatory responses through the TLR2-mediated NF- $\kappa \mathrm{B}$ and JNK pathways in the murine RAW 264.7 macrophage cell line.
\end{abstract}

\section{Introduction}

An important factor of biological material safety evaluation is to explore the toxicity effects of biological materials on cells and their proinflammatory effects. We previously reported that following coculture with the murine RAW 264.7 cell line, dicalcium silicate coating material and silicon, calcium, and other released ions showed no obvious cytotoxicity effects on RAW 264.7 cells; however, there was a potential proinflammatory response, and it increased the release of inflammatory factors [1].

Dicalcium silicate $\left(\mathrm{Ca}_{2} \mathrm{SiO}_{4}\right)$ is an important material in the calcium-silica system, which is frequently identified as an important constituent in Portland cement $[2,3]$. Previous studies have indicated that $\gamma-\mathrm{Ca}_{2} \mathrm{SiO}_{4}$ ceramic possesses good bioactivity, biocompatibility, and mechanical properties and that it might be a promising bone implant material $[4,5]$. Additionally, $\gamma-\mathrm{Ca}_{2} \mathrm{SiO}_{4}$ ceramic might be suitable for a potential application in the biomedical field, preferentially as materials for bone repair [6]. Some studies demonstrated that $\mathrm{Ca}_{2} \mathrm{SiO}_{4}$ powder ceramics and coatings are bioactive and can quickly induce the formation of a bonelike apatite layer on their surface after soaking in simulated body fluid (SBF) $[7,8]$. Dicalcium silicate $\left(\mathrm{C}_{2} \mathrm{~S}\right)$ and tricalcium phosphates (TCP) can both develop desirable physical properties as a result of undergoing hydration reactions [9], both of which were studied in this report.

Tricalcium phosphate $\left(\left(\mathrm{Ca}_{3}\left(\mathrm{PO}_{4}\right)_{2}\right)=\mathrm{TCP}\right)$ is one of the most important biomaterials based on phosphates, and once it is mixed with a liquid phase, it produces much more rapid 
bone growth and union, currently recognized as ceramic material, which significantly simulates the mineralogical structure of bone $[10,11]$ When TCP ceramics are implanted in vivo, they are nontoxic, antigenically inactive, and noncarcinogenic, and they bond directly to bone without intervening connective tissue. They show no cytotoxicity and good biological compatibility and osteoconductivity in living tissues, and they are therefore used clinically as a hard tissue replacement [12-14]. $\mathrm{Ca}_{2} \mathrm{SiO}_{4}-\mathrm{Ca}_{3}\left(\mathrm{PO}_{4}\right)_{2}$ ceramics are cytocompatible, and they are able to induce the osteoblastic differentiation of undifferentiated adult mesenchymal stem cells of human origin(ahMSCs) [15]. The ionic products of plasma-sprayed dicalcium silicate coating are beneficial to the proliferation and differentiation of MG63 osteoblastlike cells, and they differentially regulated osteoclastogenic gene expression by upregulating OPG and downregulating RANKL $[16,17]$.

The cell attachment, cytotoxicity, antibacterial efficacy, bioactivity, and biocompatibility properties of dicalcium silicate cement consistently make it a potential candidate as a root-end filling material and root sealer for endodontic use [18-20].

However, as for the mechanism of the dicalcium silicate proinflammatory response, there is no relevant research. This study aimed to detect the proinflammatory factors released from dicalcium silicate and tricalcium phosphate after being cocultured with RAW 264.7 cells and to explore their proinflammatory response mechanisms. Deeply exploring the mechanism of dicalcium silicate proinflammatory response can help further provide an understanding of the potential risks and clinical applications and provide certain references for the extensive use of dicalcium silicate materials in the clinic.

\section{Materials and Methods}

2.1. Materials. $\beta$-Dicalcium silicate $\left(\beta-\mathrm{Ca}_{2} \mathrm{SiO}_{4}\right)$ was synthesized in the Shanghai Institute of Ceramics laboratory at the Chinese Academy of Sciences [7]. $\beta$-Tricalcium phosphate (Sigma, USA) was purchased from Sigma.

\subsection{The Characterization of Dicalcium Silicate and Tricalcium} Phosphate. Surface morphologies were observed using scanning electron microscopy (SEM, Hitachi S-3400N, Japan), and elemental analyses were detected with an energy dispersive X-ray spectroscopy (EDS, IXRF system, Model 550i, USA). The crystal structure was analysed using X-ray diffraction (XRD, Empyrean XRD system, PANalytical B.V., Dutch), and the diffraction pattern was measured in the $2 \theta$ range from $10^{\circ}$ to $80^{\circ}$. The size of the two particles types was detected using laser particle size analysis (MS2000, Melvin Instrument Co. Ltd, England).

\subsection{Estimation of Endotoxin Levels on $\mathrm{C}_{2} S$ and TCP Particles.} Packaging procedures were subject to continuous endotoxin control. Particle endotoxin levels were measured using a limulus reagent, bacterial endotoxins, and the maximum valid dilution (Xiamen Limulus Reagent Laboratory Co. Ltd, Fujian, China) to exclude the possibility of proinflammatory effects arising from the bacterial contamination of the $\mathrm{C}_{2} \mathrm{~S}$ and TCP particles. The particles were dropped into endotoxin-free water and incubated with Limulus polyphemus in sterilized glass tubes at $37^{\circ} \mathrm{C}$, and the gel formation was evaluated after $1 \mathrm{~h}$.

2.4. Cell Culture. The mouse macrophage cell line, RAW 264.7 (American Type Culture Collection, TIB71, MD, USA) was used to evaluate the cytotoxicity and cytokine production induced by the $\mathrm{C}_{2} \mathrm{~S}$ and TCP. The cells were maintained in DMEM supplemented with $10 \%$ foetal calf serum (Life Technologies, USA), under a saturated $5 \% \mathrm{CO}_{2}$ and $95 \%$ air atmosphere. The cells were cocultured with $\mathrm{C}_{2} \mathrm{~S}$ and TCP. The negative controls without any material were also examined. The culture medium containing $0.64 \%$ phenol solution was used as a positive control to evaluate cell viability. The cells cultured in DMEM with $5 \mu \mathrm{g} / \mathrm{mL}$ lipopolysaccharide (LPS, Sigma, St. Louis, USA) were used as a positive control to evaluate cytokine production.

2.5. Cytotoxicity and Apoptosis Profiles in Response to Dicalcium Silicate and Tricalcium Phosphate. Murine RAW 264.7 cells were inoculated into 96-well plates with well densities of 6000 . Additionally, we set up a blank medium group, a medium + cells group, and $10 \mu \mathrm{g} / \mathrm{mL}$ and $100 \mu \mathrm{g} / \mathrm{mL}$ dicalcium silicate and tricalcium phosphate particle groups and incubated the cells for 6, 24, 48, and 72 hours. When measuring apoptosis, RAW 264.7 cells were inoculated into 6-well plates at a cell density of $1 \times 10^{6}$. Additionally, we set up a blank cell group, and we incubated cells with $10 \mu \mathrm{g} / \mathrm{mL}$ or $100 \mu \mathrm{g} / \mathrm{mL}$ concentrations of two kinds of dicalcium silicate and tricalcium phosphate particles as well as a positive control group. All six groups were incubated for 24 hours. The positive control group has no material, but it included a medium containing a $0.64 \%$ phenol solution. The cell vitality was evaluated using the cell counting kit-8 assay (CCK 8, BestBio, China).

According to the FITC Annexin V apoptosis detection kit description (BD Pharmingen ${ }^{\mathrm{TM}}$ ), the dead RAW 264.7 cells stained with both FITC Annexin V and PI. When apoptosis is measured over time, the cells can be often tracked as FITC Annexin $\mathrm{V}$ and PI negative (viable or no measurable apoptosis), to FITC Annexin V positive and PI negative (early apoptosis, membrane integrity is present), and finally to FITC Annexin V and PI positive (end stage apoptosis and death). The movement of cells through these three stages suggests apoptosis. The instrument model we utilized was a BD FACS Canto $^{\mathrm{TM}}$ II flow cytometer. After the samples were run, we used the BD FACSDiva software to dispose the result and obtain data result plots.

2.6. Oxidative Stress Response. To explore the oxidative stress response of the $\mathrm{C}_{2} \mathrm{~S}$ and TCP particles in the RAW 264.7 cells, we used a reactive oxygen species (ROS) test kit (Nanjing Jiancheng Biology Engineering Institute, Jiangsu, China) to test the superoxide dismutase (SOD) activity. An inverted fluorescence microscope and flow cytometry (FCM) were used to evaluate the ROS amounts. RAW 264.7 cells were cultured in 6-well plates, and we set up 
TABLE 1: siRNA target sequences used for quantificational realtime PCR.

\begin{tabular}{lc}
\hline Name & Target sequence \\
\hline siRNA-TLR2-1 & GTCCAGCAGAATCAATACA \\
siRNA-TLR2-2 & GCAGGCGACAACCACTTTG \\
siRNA-TLR2-3 & GGAGTCTCTGTCATGTGAT \\
\hline
\end{tabular}

groups that included a negative control group, $10 \mu \mathrm{g} / \mathrm{mL}$ or $100 \mu \mathrm{g} / \mathrm{mL} \mathrm{C}_{2} \mathrm{~S}$ and TCP particles groups, and a positive control group, in which we added $\mathrm{H}_{2} \mathrm{O}_{2}$. We extracted the cells and inspected them after they had been incubated for 6 hours.

2.7. siRNA Interference of Relative TLR2 mRNA Expression. We entrusted Guangzhou Ribobio Biology Technology Company, Ltd (Ribobio) to design and synthesize three small interfering RNAs (siRNA) to interfere with TLR2 mRNA expression. The primer sequences we used for the siRNA are listed in Table 1. According to the product manual operation, we selected and utilized a $50 \mathrm{nM}$ siRNA concentration. Murine RAW 264.7 cells were inoculated into 6-well plates at a cell density of $8 \times 10^{5}$ cells. The reaction system in each well included $120 \mu \mathrm{L}$ riboFECT ${ }^{\mathrm{TM}} \mathrm{CP}$ Buffer, $5 \mu \mathrm{L}$ siRNA, and $12 \mu \mathrm{L}$ riboFECT CP Reagent. Then, we added three different siRNAs to three different wells to test the interference efficiency. Next, we used qRT-PCR to determine the TLR2 mRNA gene expression after $48 \mathrm{~h}$. Here, we utilized five groups, including negative control, positive control, siRNATLR-1, siRNA-TLR-2, and siRNA-TLR-3 groups. The fluorescent siRNA was used to transfect the RAW 264.7 cells for $48 \mathrm{~h}$. Then, we compared the fluorescent cell numbers through an inverted fluorescence microscope with total cell amounts with a light microscope, in which the transfection efficiency of the transfection reagent could be evaluated more intuitively.

2.8. Quantitative Real-Time Polymerase Chain Reaction ( $q R T$ PCR) Analyses of Steady-State mRNA Levels of TLR2, TNF- $\alpha$, $I L-1 \beta$, and $I L-6$. RAW 264.7 cells were cultured in 6-well plates, and we set up groups that included a control group, a siRNA-control group, $10 \mu \mathrm{g} / \mathrm{mL}$ or $100 \mu \mathrm{g} / \mathrm{mL} \mathrm{C}_{2} \mathrm{~S}$ and TCP groups, $10 \mu \mathrm{g} / \mathrm{mL}$ or $100 \mu \mathrm{g} / \mathrm{mL} \mathrm{C}_{2} \mathrm{~S}$ and TCP groups plus siRNA-TLR2-1, and a $5 \mu \mathrm{g} / \mathrm{mL}$ LPS group, which were cultured for $24 \mathrm{~h}$. After $24 \mathrm{~h}$, qRT-PCR was used to detect the relative TLR2, TNF- $\alpha$, IL- $1 \beta$, and IL- 6 mRNA expression levels. The total RNA was extracted using RNAiso Plus (Takara, Japan). RNA ( $1 \mu \mathrm{g}$ ) was obtained from each sample and was reverse-transcribed using oligo-dT as the first-strand cDNA primer (revert aid first strand cDNA synthesis kit, Thermo Scientific, USA). TLR2, TNF- $\alpha$, IL- $1 \beta$, IL-6, and GAPDH primer sequences and their fragment lengths are shown in Table 2. The reverse-transcribed cDNA was subjected to qPCR (SYBY Premix Ex Taq, Takara, Japan) using the following cycling conditions: $95^{\circ} \mathrm{C}$ for $10 \mathrm{~min}$ (initial denaturation), 40 cycles of $95^{\circ} \mathrm{C}$ for $15 \mathrm{~s}$ and $60^{\circ} \mathrm{C}$ for $60 \mathrm{~s}$, and then $60^{\circ} \mathrm{C}$ for $5 \mathrm{~min}$ for terminal extension. The temperature was elevated one
TABLE 2: Primers used for quantificational real-time PCR.

\begin{tabular}{lc}
\hline Name & Primer \\
\hline GAPDH & AAGAAGGTGGTGAAGCAGG \\
& GAAGGTGGAAGAGTGGGAGT \\
TLR2 & CTGTGTTCGTGCTTTCTG \\
& AGGTAGGTCTTGGTGTTCATT \\
TNF- $\alpha$ & TTGTTGCCTCCTCTTTTGCT \\
& TGGTCACCAAATCAGCGTTA \\
IL-1 $\beta$ & CAGGCAGGCAGTATCACTCA \\
& TGTCCTCATCCTGGAAGGTC \\
IL-6 & CCGGAGAGGAGACTTCACAG \\
& TCCACGATTTCCCAGAGAAC \\
\hline
\end{tabular}

degree each $20 \mathrm{~s}$ to obtain a melting curve. The $\Delta \Delta \mathrm{Ct}$ method of relative quantification was used to determine the fold change in expression. Delta $\mathrm{Ct}(\Delta \mathrm{Ct})$ represents the difference between the target $\mathrm{Ct}$ value and the control $\mathrm{Ct}$ value for each sample: $\Delta \mathrm{Ct}=\mathrm{Ct}$ (target gene) $-\mathrm{Ct}$ (control gene). The expression was further normalized using the control $(\Delta \Delta \mathrm{Ct}=\Delta \mathrm{Ct}-\mathrm{Ct}$ (control group). The fold change in expression was then obtained as $2^{-\Delta \Delta \mathrm{Ct}}$, and a graph was plotted for $2^{-\Delta \Delta \mathrm{Ct}}$.

2.9. Cytokine Production Measurements Using ELISA. After $24 \mathrm{~h}$ of incubation, the supernatants were collected and centrifuged at $1000 \mathrm{~g}$ for $15 \mathrm{~min}$. TNF- $\alpha$, IL- $1 \beta$, and IL- 6 were measured using commercial ELISA kits (Neobioscience Technology Company). The ELISA kit sensitivities were $15 \mathrm{pg} / \mathrm{mL}$ for TNF- $\alpha, 8 \mathrm{pg} / \mathrm{mL}$ for IL- $1 \beta$, and $8 \mathrm{pg} / \mathrm{mL}$ for IL- 6 .

2.10. Western Blot Analysis for Relative Protein Expression. RAW 264.7 cells were inoculated into 6-well plates at a cell density of $1 \times 10^{6}$ cells. Then, we added nothing but RAW 264.7 cells as a negative control group, $10 \mu \mathrm{g} / \mathrm{mL}$ LPS as positive group, $10 \mu \mathrm{g} / \mathrm{mL}$ or $100 \mu \mathrm{g} / \mathrm{mL} \mathrm{C}_{2} \mathrm{~S}$ and TCP, and $10 \mu \mathrm{g} / \mathrm{mL}$ or $100 \mu \mathrm{g} / \mathrm{mL} \mathrm{C}_{2} \mathrm{~S}$ and TCP plus siRNA-TLR2-1 as experimental groups. The cells were lysed by RIPA lysis buffer with cocktail protease and phosphatase inhibitors at $4^{\circ} \mathrm{C}$ for 30 minutes. The cytoplasmic and nuclear proteins were obtained with a nuclear and cytoplasmic protein extraction kit (Beyotime) according to the manufacturer's instruction. The protein concentrations were determined with an enhanced BCA protein assay kit (Beyotime). Sixty micrograms of protein was separated via $10 \%$ SDS-PAGE and then transferred to positively charged nylon membranes. After transferring, the membranes were blocked with $5 \%$ bovine serum albumin (BSA) in TBS with $0.1 \%$ Tween-20 for $1 \mathrm{~h}$ at $37^{\circ} \mathrm{C}$ and then blotted at $4^{\circ} \mathrm{C}$ overnight with GAPDH, MyD88, p-p38, p-I $\kappa \mathrm{B}$, or p-JNK1 + JNK2 + JNK3 primary antibodies. Specific bands were detected with ECL (Advansta, USA). The Quantity One software was used to quantify the band densities.

2.11. Statistical Analysis. Bar graphs were used to show the mean and standard deviation (SD) of triplicate experiments. The data were normalized, and data that passed the normality test were analysed using one-way ANOVA with the least 


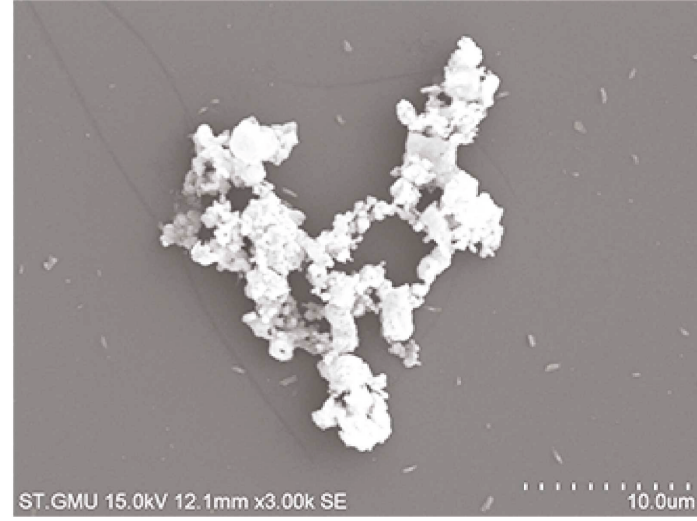

(a)

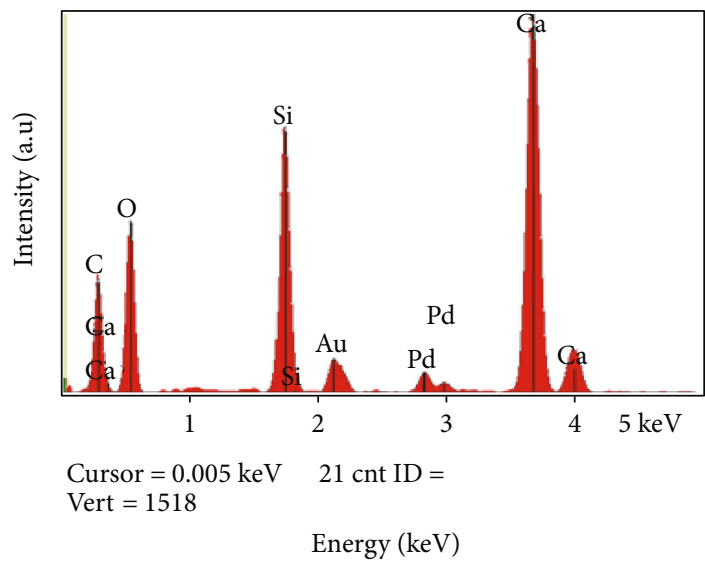

(c)

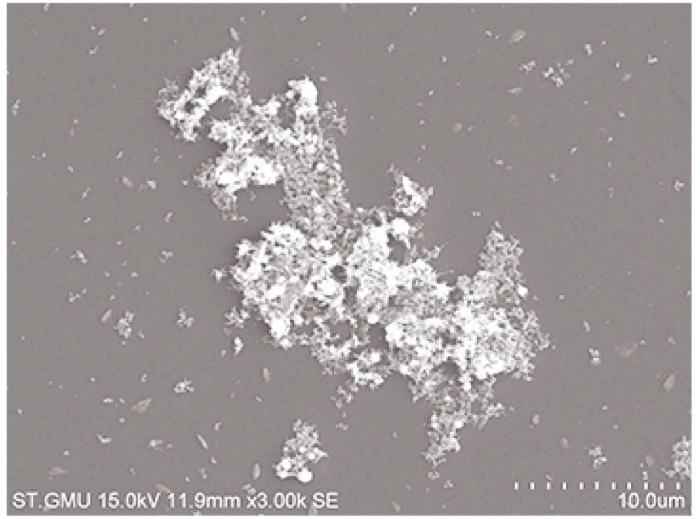

(b)

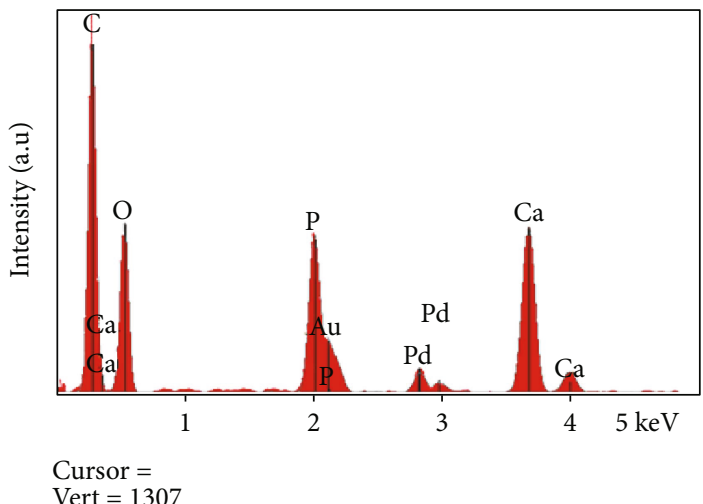

Energy (keV)

(d)

FIgURE 1: SEM photographs and EDS analysis of the two biomaterials. SEM shows the surface topography of the $\mathrm{C}_{2} \mathrm{~S}$ and TCP particles (3000x), whereas the EDS analysis shows the elemental composition of the $\mathrm{C}_{2} \mathrm{~S}$ and TCP particles. SEM photographs of (a) $\mathrm{C}_{2} \mathrm{~S}$ and (b) TCP. EDS analyses of (c) $\mathrm{C}_{2} \mathrm{~S}$ and (d) TCP.

significant difference (LSD) test. The Dunnett's test was utilized for abnormal distributions. All analyses were conducted using the SPSS 18.0 software (SPSS Inc., Chicago, IL, USA). $P$ values $<0.05$ were considered statistically significant.

\section{Results}

3.1. Characterization of Dicalcium Silicate and Tricalcium Phosphate Particle. SEM and EDS were used to evaluate the surface topography of $\mathrm{C}_{2} \mathrm{~S}$ and TCP particles. Observed under SEM (3000x), the $\mathrm{C}_{2} \mathrm{~S}$ particles presented as circular particles, but most of the particles aggregated together as a block mass, while the TCP hydrate under SEM had two different shapes: strip and grainy shapes (Figures 1(a) and 1(b)).

The EDS analysis showed that oxygen, carbon, calcium, and silica existed in the surface of dicalcium silicate particles, while carbon, calcium, phosphorus, and oxygen existed on the surface of the tricalcium phosphate particles (Figures 1(c) and 1(d)).

The XRD analysis showed that the dicalcium silicate particle collection of illustration matched $<49-1673>$ calcium silicate-matching $\mathrm{Ca}_{2} \mathrm{SiO}_{4}$ and the tricalcium phosphate particle collection of illustration matched $<18-0303>$ calcium phosphate hydrate $-\mathrm{Ca}_{3}\left(\mathrm{PO}_{4}\right)_{2} \cdot \mathrm{H}_{2} \mathrm{O}$ (Figures $2(\mathrm{a})$ and $2(\mathrm{~b})$ ).
The laser particle size analysis results showed that the $\mathrm{C}_{2} \mathrm{~S}$ particles had one main size, approximately $8.710-10.000 \mu \mathrm{m}$, while the TCP particles had two main sizes, approximately 1.660-1.905 $\mu \mathrm{m}$ and 8.710-10.000 $\mu \mathrm{m}$ (Figures 2(c) and 2(d)).

3.2. Estimation of Endotoxin Levels on $C_{2} S$ and TCP Particles. The particles were dropped into endotoxin-free water and incubated with Limulus polyphemus in sterilized glass tubes at $37^{\circ} \mathrm{C}$, and the gel formation was evaluated after $1 \mathrm{~h}$. No gel was generated in the control or in the $10 \mu \mathrm{g} / \mathrm{mL}$ and $100 \mu \mathrm{g} / \mathrm{mL}$ C2S and TCP particle groups, while the gel was produced in the positive control group, which contained bacterial endotoxin. The sensitivity of the Limulus polyphemus was $0.03 \mathrm{EU} / \mathrm{mL}$.

3.3. Cytotoxicity and Apoptosis Profiles in Response to Dicalcium Silicate and Tricalcium Phosphate. To evaluate the cell proliferation and cell toxicity, we used a CCK- 8 cell proliferation test kit (Betboy, China) in accordance with the manufacturer's instructions. RAW 264.7 cells were cultured with $10 \mu \mathrm{g} / \mathrm{mL}$ and $100 \mu \mathrm{g} / \mathrm{mL} \mathrm{C}_{2} \mathrm{~S}$ and TCP materials for $6 \mathrm{~h}, 24 \mathrm{~h}, 48 \mathrm{~h}$, and $72 \mathrm{~h}$. Following culture with these two particle types, the RAW 264.7 cell growth over time was not affected, no matter the particle concentration $(10 \mu \mathrm{g} / \mathrm{mL}$ 


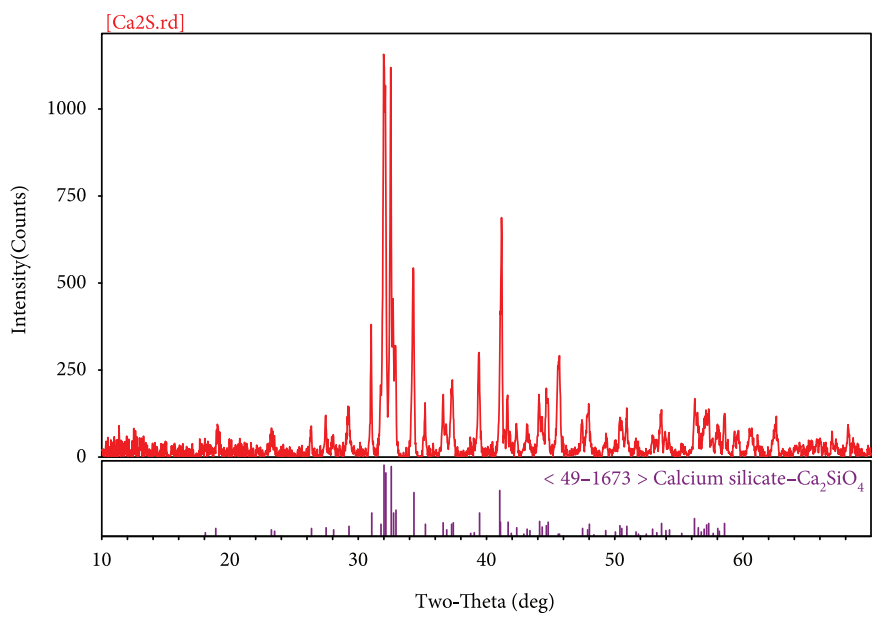

(a)

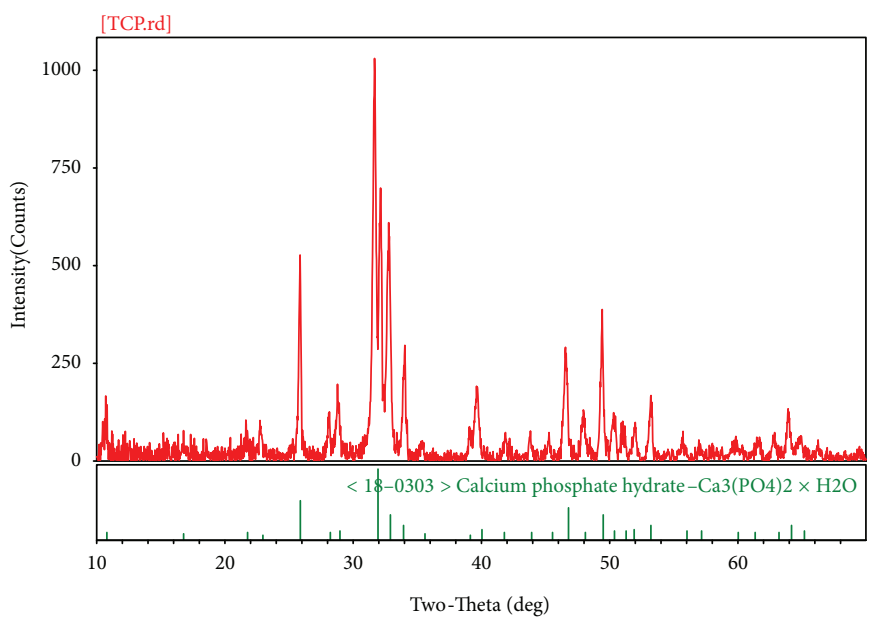

(b)

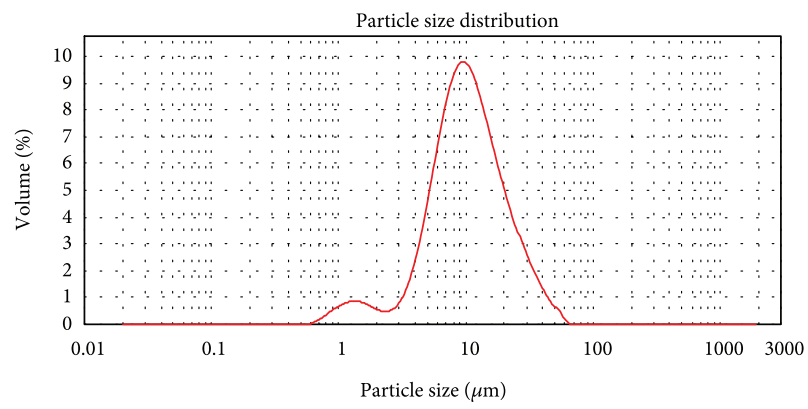

(c)

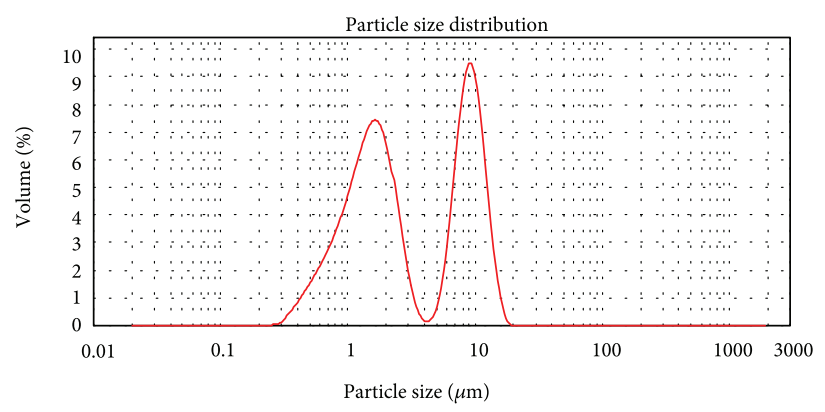

(d)

FIGURE 2: The XRD patterns of the two biomaterials and the size of the two particle types detected by particle size analysis: (a) XRD patterns of $\mathrm{C}_{2} \mathrm{~S}$, (b) XRD patterns of TCP, (c) the size distribution of the $\mathrm{C}_{2} \mathrm{~S}$ particles, and (d) the size distribution of the TCP particles.

or $100 \mu \mathrm{g} / \mathrm{mL}$ ), which indicated no obvious cytotoxicity (Figure 3). Following the CCK-8 proliferation test evaluation, over $90 \%$ of the cells were activated in the material groups (Figure 3).

According to the description of the FITC Annexin V apoptosis detection kit (BD Pharmingen), the movement of cells through the three stages suggested apoptosis; therefore, we counted the FITC Annexin V positive and PI negative cells and the FITC Annexin V and PI positive cells. Figure 4(g) shows that the apoptosis in the groups and whether there was a significant difference between them. Compared with the control group, there was no obvious difference when the cells were cocultured with $10 \mu \mathrm{g} / \mathrm{mL}$ or $100 \mu \mathrm{g} / \mathrm{mL}$ TCP or $\mathrm{C}_{2} \mathrm{~S}$; however, remarkable differences were observed between the negative and positive control groups $(P<0.01)$.

3.4. Oxidative Stress Response. According to the description of the ROS test kit, we used an inverted fluorescence 


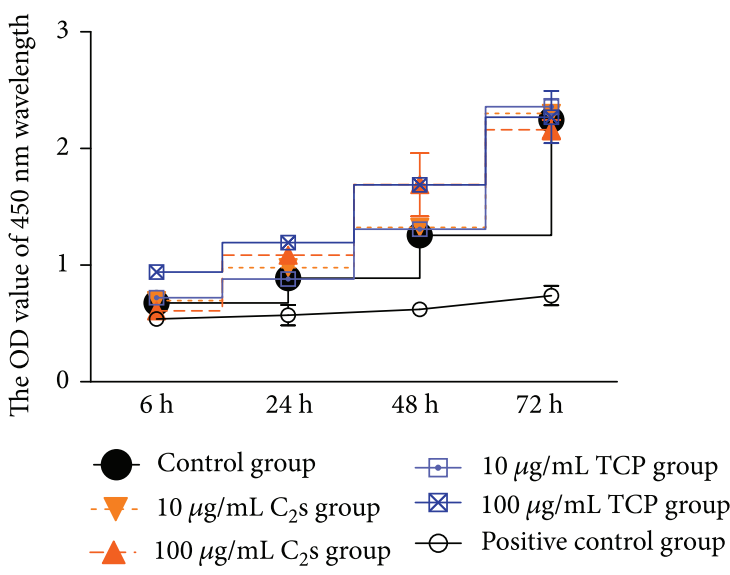

(a)

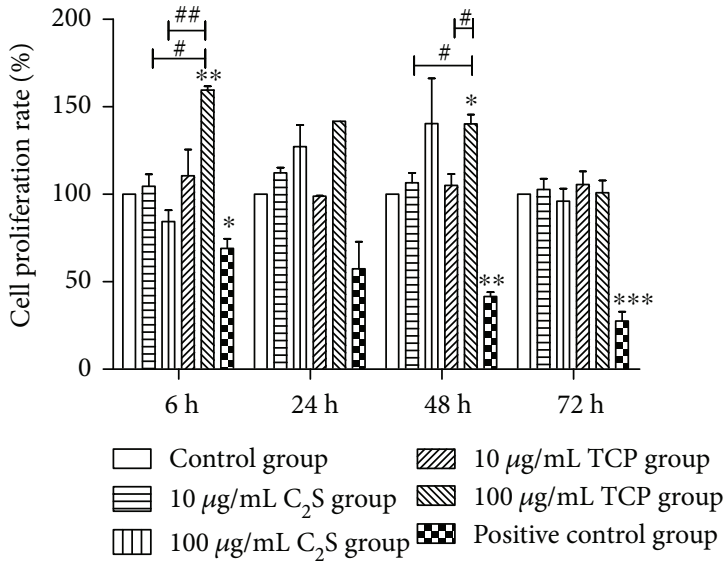

(b)

FIgURE 3: The OD values at $450 \mathrm{~nm}$ wavelength (a) and the cell proliferation rate (b) of the RAW 264.7 cells after being cocultured with $\mathrm{C}_{2} \mathrm{~S}$ and TCP for $6 \mathrm{~h}, 24 \mathrm{~h}, 48 \mathrm{~h}$, and $72 \mathrm{~h}$. (a) The OD values at $450 \mathrm{~nm}$ wavelength of experimental groups were almost higher than in the control group. The positive control group showed low OD values at $450 \mathrm{~nm}$ wavelength. (b) More than $90 \%$ of the cells were viable in the experimental groups, and the proliferation rate was low in the positive control group. A higher proliferation rate was observed at $100 \mu \mathrm{g} / \mathrm{mL}$ TCP compared with $10 \mu \mathrm{g} / \mathrm{mL}(P<0.05)$ and $100 \mu \mathrm{g} / \mathrm{mL} \mathrm{C} \mathrm{S}(P<0.01)$ after being cocultured for $6 \mathrm{~h}$. Additionally, $100 \mu \mathrm{g} / \mathrm{mL}$ TCP produced a higher proliferation rate than the $10 \mu \mathrm{g} / \mathrm{mL}$ of TCP $(P<0.05)$ and $\mathrm{C}_{2} \mathrm{~S}(P<0.05)$ cocultured for $48 \mathrm{~h} .{ }^{*} P<0.05$, ${ }^{* *} P<0.01$, and ${ }^{* * *} P<0.001$ (experimental group versus control group). ${ }^{\#} P<0.05$, ${ }^{\# \#} P<0.01$, and ${ }^{\# \# \# ~} P<0.001\left(\mathrm{C}_{2} \mathrm{~S}\right.$ versus TCP).

microscope and FITC of FCM to evaluate the amount of ROS produced by the negative control, positive control, and $10 \mu \mathrm{g} / \mathrm{mL}$ or $100 \mu \mathrm{g} / \mathrm{mL} \mathrm{C}_{2} \mathrm{~S}$ or TCP particle groups.

As the result shows, compared with control group, which had a mean fluorescence intensity of 684 , the $10 \mu \mathrm{g} / \mathrm{mL} \mathrm{C}_{2} \mathrm{~S}$ and TCP particle groups showed hypofluorescence and produced less ROS, with mean fluorescence intensities of 121 and 575 , respectively. While the $100 \mu \mathrm{g} / \mathrm{mL} \mathrm{C}_{2} \mathrm{~S}$ and TCP particle groups showed hyperfluorescence and more obvious ROS, with mean fluorescence intensities of 6374 and 1682, respectively. In the positive control group, we observed hyperfluorescence and distinct ROS with a mean fluorescence intensity of 2140 (Figure 5).

3.5. siRNA Interfered with the TLR2 mRNA Expression. We use three siRNAs provided by the Ribobio Biology Company to interfere with the TLR2 mRNA expression. We directly observed the fluorescent and common cell amounts with an inverted fluorescence microscope to evaluate the transfection efficiency of the transfection reagents and detected the TLR2 mRNA expression levels to determinate the interference effect.

Obviously, the number of fluorescent cells observed under the inverted fluorescence microscope (Figure 6(b)) was almost the same as the number of common cells observed under the ordinary red light microscope (Figure 6(a)). The TLR2 mRNA levels of positive control group were significantly decreased $(P<0.01)$. Both siRNA-TLR2-1 and siRNA-TLR2-2 had obvious interference effects, with efficiencies of approximately $56 \%$ and $60 \%$, respectively, compared with the negative control groups. These differences were statistically significant $(P<0.05)$. The siRNA-TLR2-3 interference effect was not ideal compared with the negative control group. This difference was not statistically significant
(Figure 6(c)). Therefore, we selected siRNA-TLR2-1, whose interference effect was the most ideal, in the follow-up studies.

3.6. The Relative Gene Expression. To determine the effects of the $\mathrm{C}_{2} \mathrm{~S}$ particles on proinflammatory mediator expression in macrophages, TLR2, TNF- $\alpha$, IL- $1 \beta$, and IL- 6 mRNA levels were tested using RT-qPCR. The cells were harvested $24 \mathrm{~h}$ after cultivation. The LPS-treated cells were used as positive controls.

The TLR2 mRNA levels in the RAW 264.7 cells were not obviously changed after being cocultured with $10 \mu \mathrm{g} / \mathrm{mL}$ and $100 \mu \mathrm{g} / \mathrm{mL}$ TCP and $\mathrm{C}_{2} \mathrm{~S}$ for $6 \mathrm{~h}$. A significant increase in TLR2 mRNA levels were observed for the $10 \mu \mathrm{g} / \mathrm{mL}$ $(P<0.01)$ and $100 \mu \mathrm{g} / \mathrm{mL}(P<0.05) \mathrm{C}_{2} \mathrm{~S}$ particle groups after $24 \mathrm{~h}$. The TLR2 mRNA expression in the $10 \mu \mathrm{g} / \mathrm{mL} \mathrm{C} \mathrm{C}_{2} \mathrm{~S}$ group was significantly higher than the $100 \mu \mathrm{g} / \mathrm{mL}$ TCP group $(P<0.05)$. A positive significant increase was observed $(P<0.001)$ (Figure 6(a)). When we added siRNA-TLR2-1 to the experimental groups, the TLR2 mRNA expression in the $100 \mu \mathrm{g} / \mathrm{mL} \mathrm{C}_{2} \mathrm{~S}(P<0.05), 10 \mu \mathrm{g} / \mathrm{mL}$ TCP $(P<0.05)$, and $100 \mu \mathrm{g} / \mathrm{mL}$ TCP $(P<0.01)$ groups obviously decreased (Figure 7(b)).

The LPS induced high levels of TNF- $\alpha$ expression after $24 \mathrm{~h}$. After $24 \mathrm{~h}$, the $100 \mu \mathrm{g} / \mathrm{mL} \mathrm{C}_{2} \mathrm{~S}$ particle group significantly promoted TNF- $\alpha$ mRNA expression $(P<0.05)$. The TNF- $\alpha$ mRNA levels between the $10 \mu \mathrm{g} / \mathrm{mL}$ and $100 \mu \mathrm{g} / \mathrm{mL}$ $\mathrm{C}_{2} \mathrm{~S}$ groups and the $10 \mu \mathrm{g} / \mathrm{mL}$ and $100 \mu \mathrm{g} / \mathrm{mL}$ TCP groups were significantly different $(P<0.05)$. Additionally, when we added siRNA-TLR2- 1 to them, the TNF- $\alpha$ mRNA expression in the $10 \mu \mathrm{g} / \mathrm{mL}$ and $100 \mu \mathrm{g} / \mathrm{mL} \mathrm{C}_{2} \mathrm{~S}$ went down; however, no significant differences were observed between the $10 \mu \mathrm{g} / \mathrm{mL}$ and $100 \mu \mathrm{g} / \mathrm{mL} \mathrm{C}_{2} \mathrm{~S}+$ siRNA-TLR2-1 groups, the $10 \mu \mathrm{g} / \mathrm{mL}$ and $100 \mu \mathrm{g} / \mathrm{mL}$ TCP groups, or the $10 \mu \mathrm{g} / \mathrm{mL}$ and $100 \mu \mathrm{g} / \mathrm{mL}$ TCP + siRNA-TLR2-1 groups. The $10 \mu \mathrm{g} / \mathrm{mL}$ and 


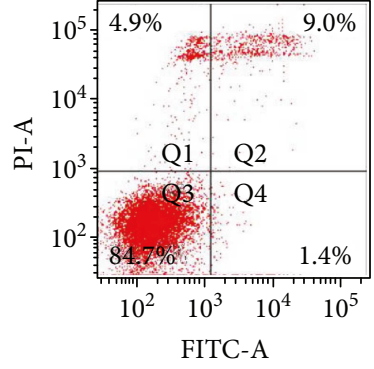

(a)

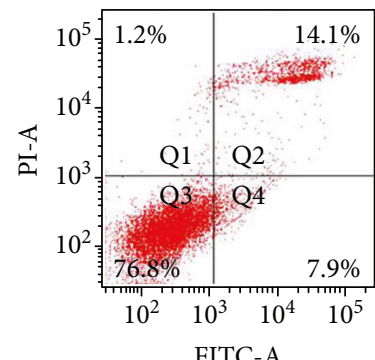

(e)

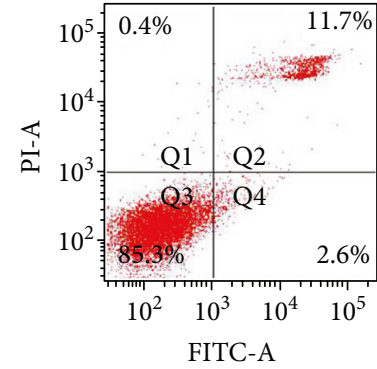

(b)

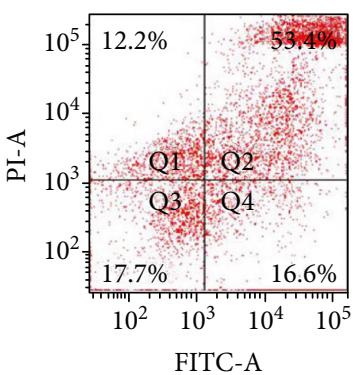

(f)

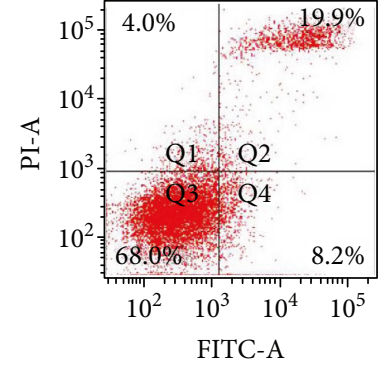

(c)

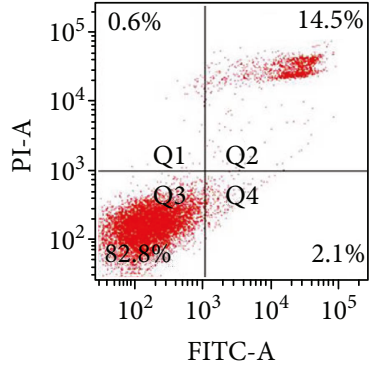

(d)

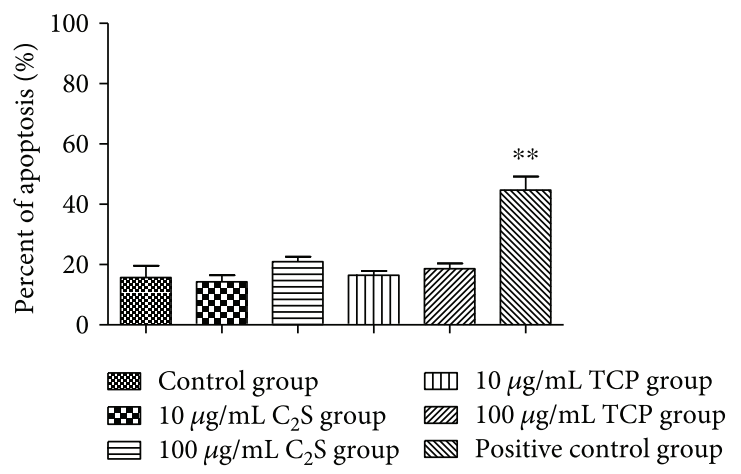

(g)

Figure 4: RAW 264.7 cells alone (a) and RAW 264.7 cells cultured with $10 \mu \mathrm{g} / \mathrm{mL} \mathrm{C}_{2} \mathrm{~S}, 100 \mu \mathrm{g} / \mathrm{mL} \mathrm{C} \mathrm{S}, 10 \mu \mathrm{g} / \mathrm{mL} \mathrm{TCP}, 100 \mu \mathrm{g} / \mathrm{mL} \mathrm{TCP}$, or $0.64 \%$ phenol solution ( $\mathrm{b}, \mathrm{c}, \mathrm{d}$, e, and f). Approximately $14.7 \%$ of the RAW 264.7 cells underwent apoptosis in the control group; approximately $14.3 \%$ and $20.9 \%$ of the cells underwent apoptosis in the $10 \mu \mathrm{g} / \mathrm{mL}$ and $100 \mu \mathrm{g} / \mathrm{mL} \mathrm{C}_{2} \mathrm{~S}$ particle groups, respectively; approximately $16.4 \%$ and $18.6 \%$ of the cells underwent apoptosis in the $10 \mu \mathrm{g} / \mathrm{mL}$ and $100 \mu \mathrm{g} / \mathrm{mL}$ of TCP groups, respectively. When the material concentrations were increased tenfold, no obvious apoptosis changes were observed. No significant difference was found amongst these groups (g) except for in the positive control group (44.7\% cells underwent apoptosis compared with the control group, $P<0.01)$. All values are represented as the mean \pm SD of triplicate experiments.

$100 \mu \mathrm{g} / \mathrm{mL}$ TCP treatments produced low levels of TNF- $\alpha$ mRNA expression $(P<0.05)$ (Figures $7(\mathrm{c})$ and $7(\mathrm{f})$ ).

Next, we examined IL-1 $\beta$ mRNA levels. No significant increase in IL- $1 \beta$ mRNA was observed in the $\mathrm{C}_{2} \mathrm{~S}$ and TCP groups, no matter their concentration (i.e., $10 \mu \mathrm{g} / \mathrm{mL}$ or $100 \mu \mathrm{g} / \mathrm{mL})$. The positive control group expressed high IL-1 $\beta$ mRNA levels after $24 \mathrm{~h}$ of cultivation $(P<0.001)$. The $100 \mu \mathrm{g} / \mathrm{mL}$ TCP treatment produced low levels of IL- $1 \beta$ mRNA expression $(P<0.05)$ (Figures $7(\mathrm{~d})$ and $7(\mathrm{~g})$ ).

Subsequently, IL-6 mRNA expression was detected (Figures 7(e) and 7(h)). Low levels of IL-6 mRNA were observed in the $10 \mu \mathrm{g} / \mathrm{mL}$ and $100 \mu \mathrm{g} / \mathrm{mL}$ TCP and $\mathrm{C}_{2} \mathrm{~S}$ particle groups after $24 \mathrm{~h}(P<0.05)$. At this time, high IL-6 mRNA levels were observed in the positive control group $(P<0.05)$. When we added siRNA-TLR2-1, the IL-6 levels slightly declined. No significant difference in IL-6 mRNA expression was observed between the $\mathrm{C}_{2} \mathrm{~S}$ and TCP particle groups $(P>0.05)$. The $10 \mu \mathrm{g} / \mathrm{mL}$ and $100 \mu \mathrm{g} / \mathrm{mL}$ TCP treatments produced low IL- 6 mRNA expression levels $(P<0.05)$ (Figures 7(e) and 7(h)).

3.7. Proinflammatory Cytokine Production Measured with ELISAs. Based on our RT-qPCR results, ELISAs were used to detect the effects of $\mathrm{C}_{2} \mathrm{~S}$ and TCP particles on TNF- $\alpha$, IL- $1 \beta$, and IL- 6 proinflammatory cytokine production after $24 \mathrm{~h}$. TNF- $\alpha$ concentrations were increased in the $10 \mu \mathrm{g} / \mathrm{mL}$ and $100 \mu \mathrm{g} / \mathrm{mL} \mathrm{C}_{2} \mathrm{~S}$ and TCP particle groups compared with the control group $(P<0.001)$. After we added siRNA-TLR2-1, the concentration decreased significantly $(P<0.001)$. No significant differences in TNF- $\alpha$ concentration were observed between the $10 \mu \mathrm{g} / \mathrm{mL} \mathrm{C}_{2} \mathrm{~S}$ and TCP particle groups. Nevertheless, the $100 \mu \mathrm{g} / \mathrm{mL} \mathrm{C}_{2} \mathrm{~S}$ particles induced a larger increase in TNF- $\alpha$ cytokine levels than the $100 \mu \mathrm{g} / \mathrm{mL}$ TCP particles $(P<0.001)$ (Figures $8(\mathrm{a})$ and $8(\mathrm{~d}))$.

Next, we examined IL- $1 \beta$ levels. There was no significant difference between the groups regarding the IL- $1 \beta$ concentration, including the group that added LPS (Figures 8(b) and $8(\mathrm{e}))$.

Finally, we measured the IL-6 concentration in all groups. The $10 \mu \mathrm{g} / \mathrm{mL}$ and $100 \mu \mathrm{g} / \mathrm{mL} \mathrm{C}_{2} \mathrm{~S}$ and TCP particle groups did not induce high IL-6 concentration levels, while the LPS strongly induced IL-6 expression (Figures 8(c) and $8(f))$.

3.8. Relative Protein Expression. To explore the mechanism of proinflammatory mediator expression in RAW 264.7 cells, the relative GAPDH, myeloid differentiation factor 88 (MyD88), p-p38, p-I $\kappa \mathrm{B}$, and $\mathrm{p}-\mathrm{JNK} 1+\mathrm{JNK} 2+\mathrm{JNK} 3$ protein expression levels were detected using Western blot analysis.

TLR signaling pathways can be largely classified as MyD88-dependent pathways, which recruits MyD88 paired with MyD88-like protein (Mal, also called TIRAP) and induces the production of inflammatory cytokines. 


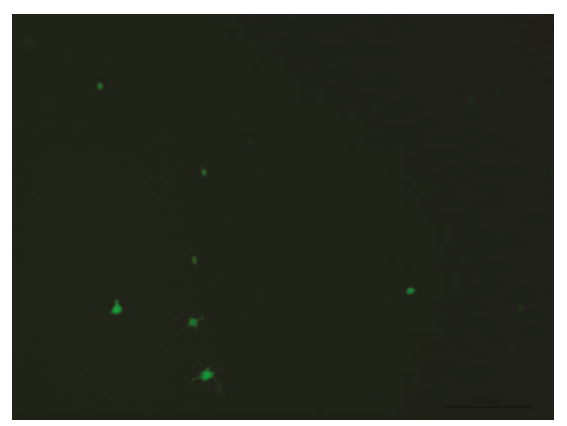

(a)

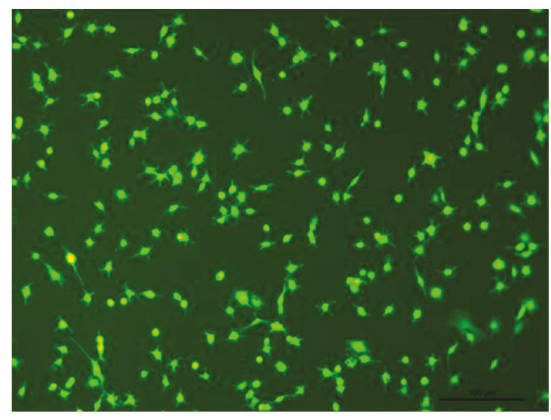

(c)

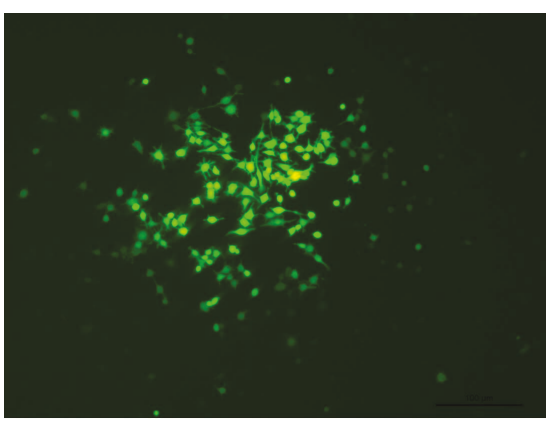

(e)

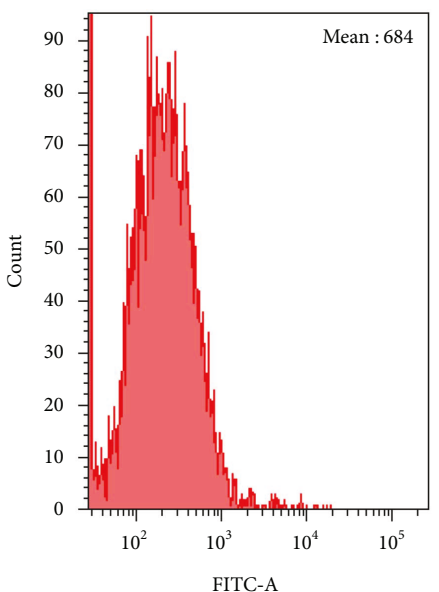

(g)

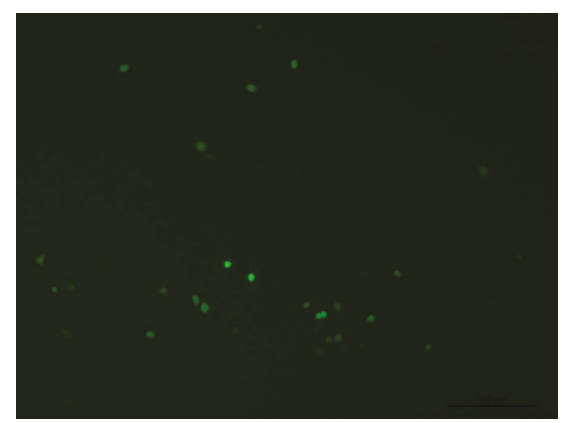

(b)

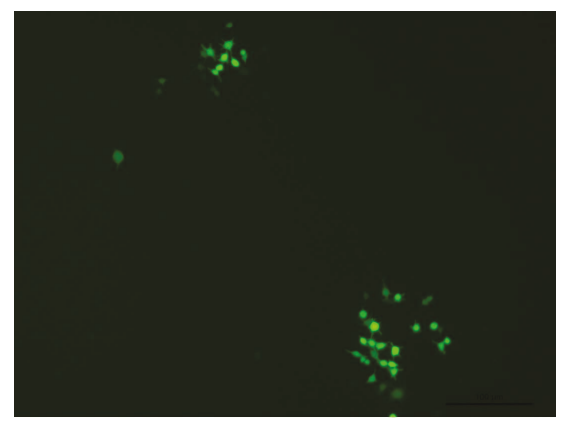

(d)

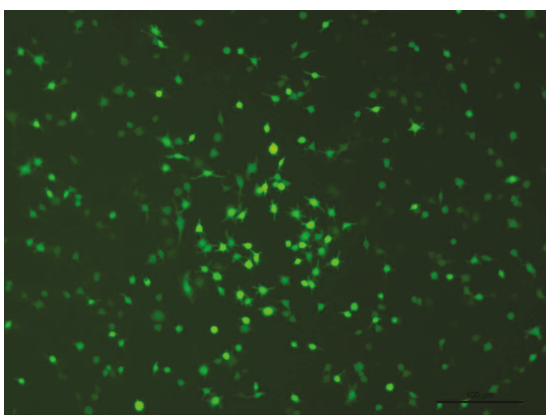

(f)

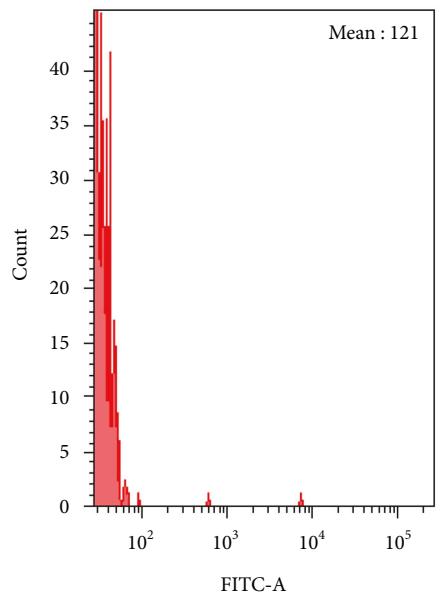

(h)

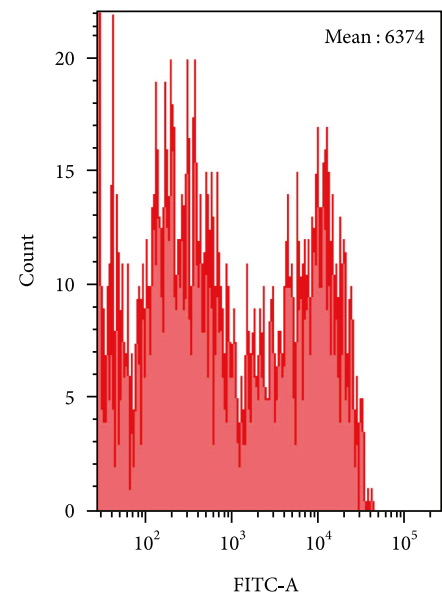

(i)

Figure 5: Continued. 


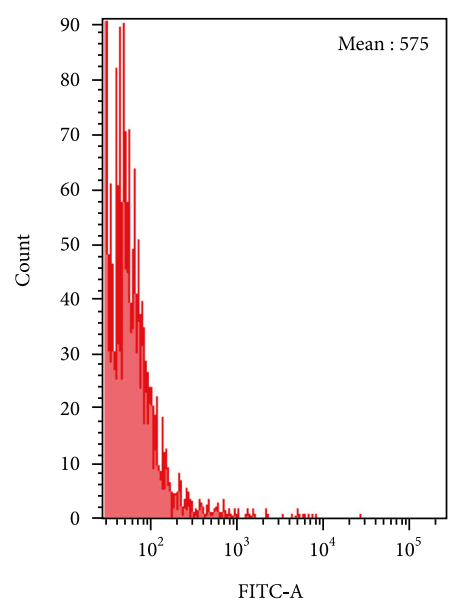

(j)

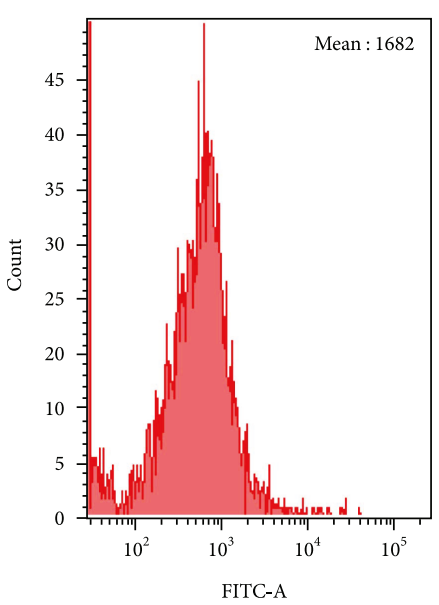

$(\mathrm{k})$

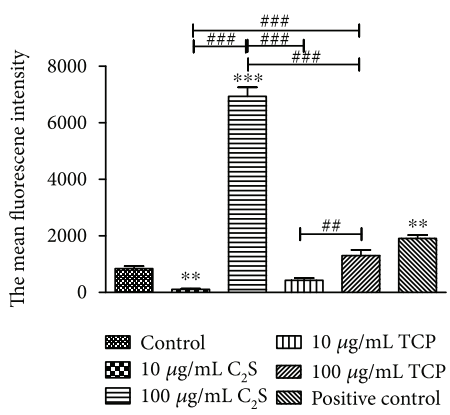

$(\mathrm{m})$

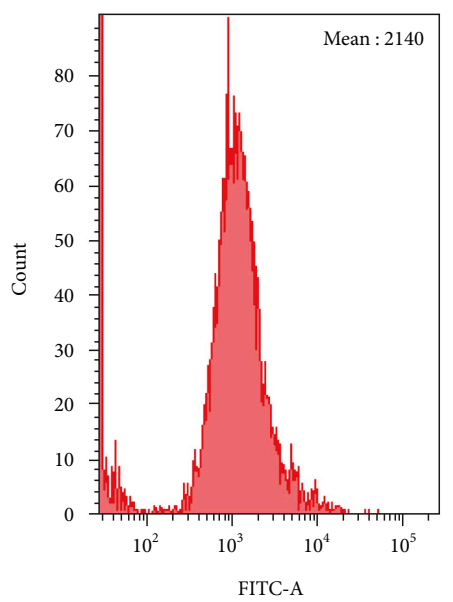

(1)

Figure 5: (a), (b), (c), (d), (e), and (f) were captured using an inverted fluorescence microscope, while (g), (h), (i), (j), (k), and (l) were acquired using FCM, which also produced the mean fluorescence intensity of the groups. (a and g) Control group, (b and h) $10 \mu \mathrm{g} / \mathrm{mL} \mathrm{C}_{2} \mathrm{~S}$ particle group, (c and i) $100 \mu \mathrm{g} / \mathrm{mL} \mathrm{C}_{2} \mathrm{~S}$ particle group, ( $\mathrm{d}$ and j) $10 \mu \mathrm{g} / \mathrm{mL} \mathrm{TCP}$ particle group, (e and k) $100 \mu \mathrm{g} / \mathrm{mL}$ TCP particle group, and (f and l) positive control group. (m) A cartogram of the mean fluorescence intensity. The $10 \mu \mathrm{g} / \mathrm{mL} \mathrm{C}_{2} \mathrm{~S}$ (compared with control group, $P<0.01$ ) and TCP particle groups showed no obvious ROS and had even lower levels than in the control group. However, when the concentration was brought up to $100 \mu \mathrm{g} / \mathrm{mL}$, a large amount of ROS was produced. Moreover, the $100 \mu \mathrm{g} / \mathrm{mL} \mathrm{C}_{2} \mathrm{~S}$ particle group generated more ROS than the $10 \mu \mathrm{g} / \mathrm{mL}(P<0.001)$ and $100 \mu \mathrm{g} / \mathrm{mL}(P<0.001)$ TCP particle groups as well as the $10 \mu \mathrm{g} / \mathrm{mL} \mathrm{C}_{2} \mathrm{~S}$ particle group, as shown above. Significant changes were observed between the $10 \mu \mathrm{g} / \mathrm{mL}$ and the $100 \mu \mathrm{g} / \mathrm{mL}$ TCP particle groups $(P<0.01)$ and the $10 \mu \mathrm{g} / \mathrm{mL} \mathrm{C}_{2} \mathrm{~S}$ particle group $(P<0.001)$. The RAW 264.7 cells produced obvious ROS when incubated with $\mathrm{H}_{2} \mathrm{O}_{2}(P<0.01)$. ${ }^{*} P<0.05$, ${ }^{* *} P<0.01$, and ${ }^{* * *} P<0.001$ (experimental group versus control group). ${ }^{\#} P<0.05,{ }^{\# \#} P<0.01$, and ${ }^{\# \# \# ~} P<0.001$ (between the experimental groups).

First, we set up seven groups to test the relative GAPDH expression and made sure that the total protein levels in each group were almost the same (Figure 9(a)).

Then, the relative expression of the phosphorylated proteins, p-p38, p-I $\kappa B$, and p-JNK1 + JNK2 + JNK3 was tested to explore the proinflammation response mechanism. Compared with the control group, the $100 \mu \mathrm{g} / \mathrm{mL} \mathrm{C}_{2} \mathrm{~S}$ particle group produced high $\mathrm{p}-\mathrm{I} \kappa \mathrm{B}(P<0.01)$ and $\mathrm{p}$-JNK1 + JNK2 + JNK3 expression levels $(P<0.01)$. When we added siRNA-TLR2-1, the expression significantly decreased. The $100 \mu \mathrm{g} / \mathrm{mL}$ TCP particle group induced low p-p38 levels $(P<0.001)$ and high $\mathrm{p}-\mathrm{I} \kappa \mathrm{B}$ levels $(P<0.001)$; moreover, it induced lower p-p38 $(P<0.01)$ and higher $\mathrm{p}-\mathrm{I} \kappa \mathrm{B}$ levels $(P<0.01)$ than the $100 \mu \mathrm{g} / \mathrm{mL} \mathrm{C}_{2} \mathrm{~S}$ particle group. When we added siRNA-TLR2-1, the $100 \mu \mathrm{g} / \mathrm{mL}$ TCP particle group induced lower p-p38 $(P<0.01)$ and higher $\mathrm{p}-\mathrm{I} \kappa \mathrm{B}$ $(P<0.01)$ than the $100 \mu \mathrm{g} / \mathrm{mL} \mathrm{C}_{2} \mathrm{~S}$ particle group. The LPS-treated group induced high p-p38 levels $(P<0.001)$ and low p-I $\kappa$ B levels $(P<0.01)$ (Figures $9(\mathrm{~b})-9(\mathrm{~d}))$.
Lastly, the relative MyD88 expression levels were tested. No significant change in relative MyD88 expression was observed in the experimental and positive control groups. When we added siRNA-TLR2-1, no obvious decrease was observed (Figure 9(e)).

\section{Discussion}

Many research studies have been conducted on $\mathrm{C}_{2} \mathrm{~S}$, which have revealed that $\mathrm{C}_{2} \mathrm{~S}$ materials exhibit many ideal characteristics. $\mathrm{C}_{2} \mathrm{~S}$ and TCP have ideal physical properties by hydration reaction [9], and compared with TCP and hydroxyapatite (HAp), $\beta-\mathrm{C}_{2} \mathrm{~S}$ has a higher strength value [21]. $\mathrm{C}_{2} \mathrm{~S}$ materials have good biological activity and electrical conductivity $[22,23]$, and $\mathrm{C}_{2} \mathrm{~S}$ is usually regarded as a potential coating material in orthopaedic and dental implant coating materials, because of its good biocompatibility and biological activity [24]. The study found that a new type of $\alpha^{\prime} \mathrm{L}+\beta-\mathrm{C}_{2} \mathrm{~S}_{\mathrm{ss}}$ cement paste can support cell adhesion and 


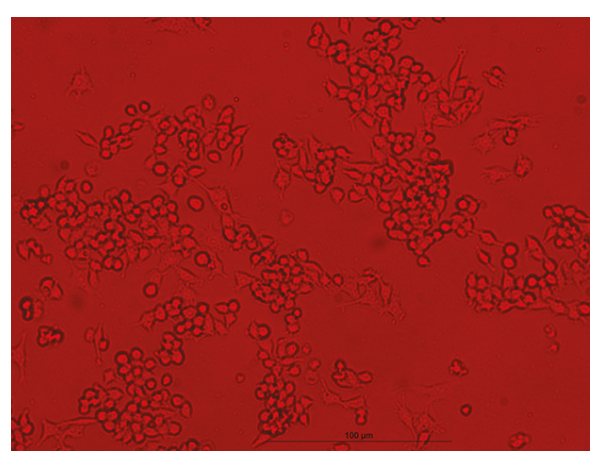

(a)

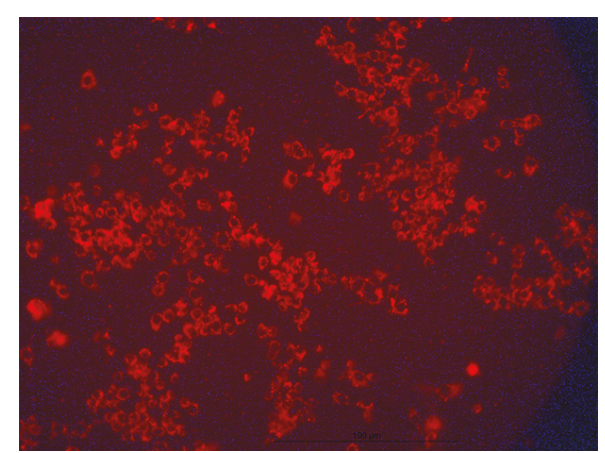

(b)

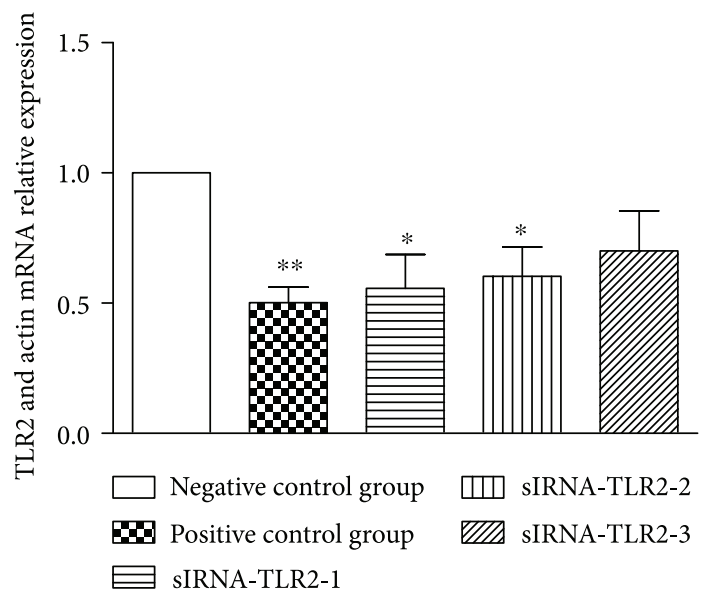

(c)

Figure 6: (a) RAW 264.7 cells with RNA oligo captured by a red light microscope. (b) RAW 264.7 cells with RNA oligo captured by an inverted fluorescence microscope. (c) The TLR2 mRNA expression in RAW 264.7 cells after siRNA-TLR2-2 interference. The positive group showed a significant decrease in TLR2 mRNA expression $(P<0.01)$. Additionally, both siRNA-TLR2-1 and siRNA-TLR2-2 had obvious interference effects $(P<0.05)$. ${ }^{*} P<0.05$ and ${ }^{* *} P<0.01$. No special explanation means experimental versus control group.

diffusion and also found that it was beneficial to the early stage of bone regeneration. [25] Additionally, studies have found that calcium silicate ion release materials provide a good microenvironment for the survival and differentiation of human oral and maxillofacial mesenchymal stem cells (OFMSCs), and the combination of calcium silicate materials and OFMSCs can promote tissue regeneration for periapical bone defects [26].

Moreover, the potential applications of $\alpha^{\prime} \mathrm{H}-\mathrm{C}_{2} \mathrm{~S}$ dicalcium silicate material in medicine may be preferred as bone or dental restorative materials by studying the characteristics, biological activity, and biocompatibility of $\alpha^{\prime} \mathrm{H}-\mathrm{C}_{2} \mathrm{~S}$ dicalcium silicate bone cement doping with TCP [27]. Bone or dental restorative materials should not produce obvious inflammation reactions. However, most studies focused on the safety and osteogenesis effect of $\mathrm{C}_{2} \mathrm{~S}$ ion products [28] and the interaction between material and immune cells. However, its potential proinflammatory response has not been explored, which limits its wide clinical applications.

TCP has not been extensively researched. Some scholars studied $\beta$-tricalcium phosphate porous bioceramics and found that after periodontal ligament cells (PDLCs) were cultured in vitro with $\beta$-TCP composite, they could proliferate and differentiate in the body and form a connective tissue, thus proving that it is feasible for $\beta$-TCP to act as scaffold materials in periodontal tissue engineering [29]. Some established a femoral head necrosis model and proved that it can be used in necrotic bone defect repair if compounded with bone marrow mesenchymal stem cells [30]. TCP coating can also delay the in vivo degradation of magnesium alloy, resulting in good biological activity [31]. The study of TCP has been relatively mature.

First, the materials were characterized using SEM, EDS, and XRD. The $\mathrm{C}_{2} \mathrm{~S}$ particles we studied, a kind of micron material, presented as circular particles but most aggregated together as a block mass, and they consisted of oxygen, carbon, calcium, and silica elements. The TCP particles we studied, a kind of micron material, were observed as strip and grainy shapes in the SEM, and they were made up of carbon, calcium, phosphorus, and oxygen elements. The endotoxin levels on $\mathrm{C}_{2} \mathrm{~S}$ and TCP particles were kept under $0.03 \mathrm{EU} / \mathrm{mL}$. Next, the cytotoxicity and apoptosis profiles of the RAW 264.7 cells in response to the $\mathrm{C}_{2} \mathrm{~S}$ and TCP particles were tested using CCK-8 kit and FITC Annexin V apoptosis detection kits. Most of the cells were viable after being cocultured with $10 \mu \mathrm{g} / \mathrm{mL}$ and $100 \mu \mathrm{g} / \mathrm{mL} \mathrm{C}_{2} \mathrm{~S}$ and TCP particles 


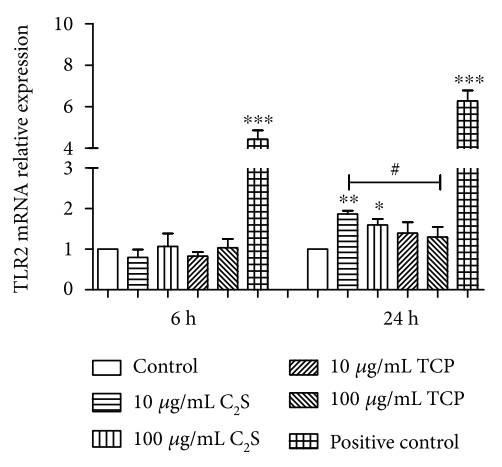

(a)

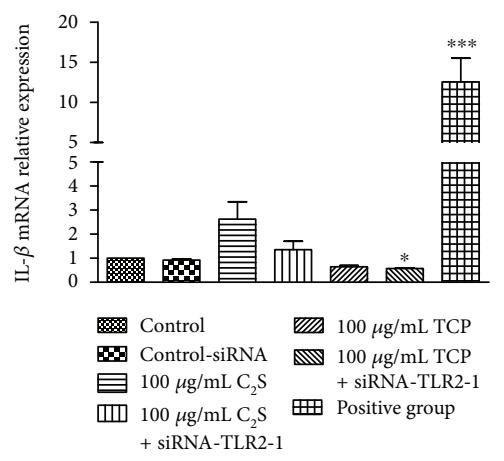

(d)

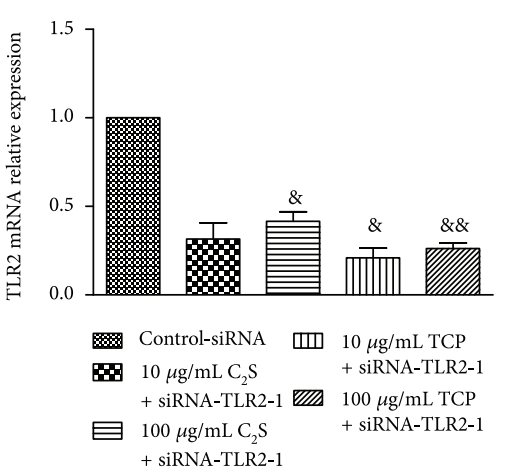

(b)

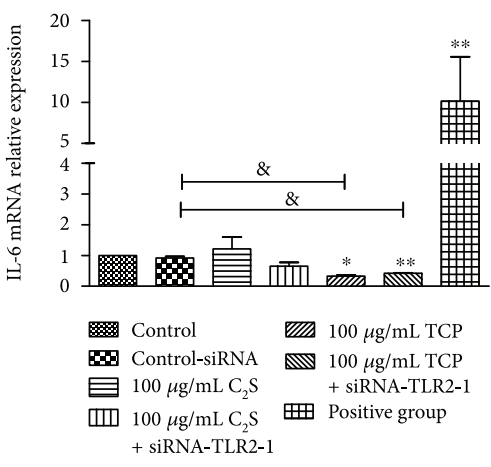

(e)

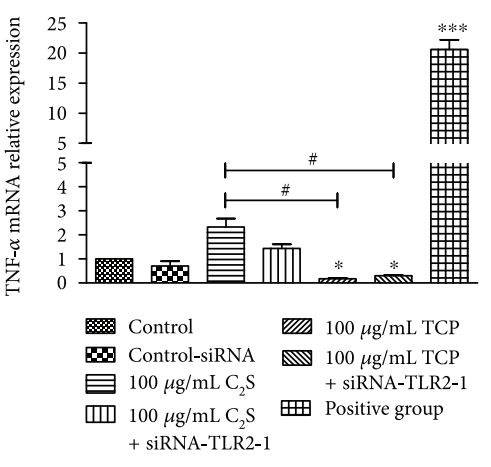

(c)

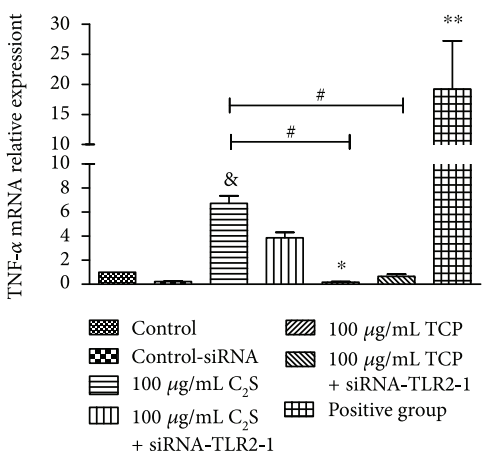

(f)

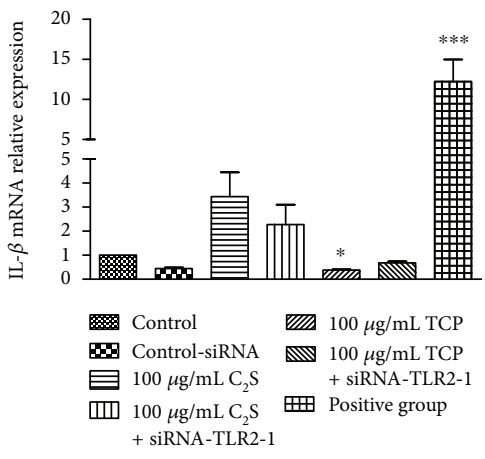

(g)

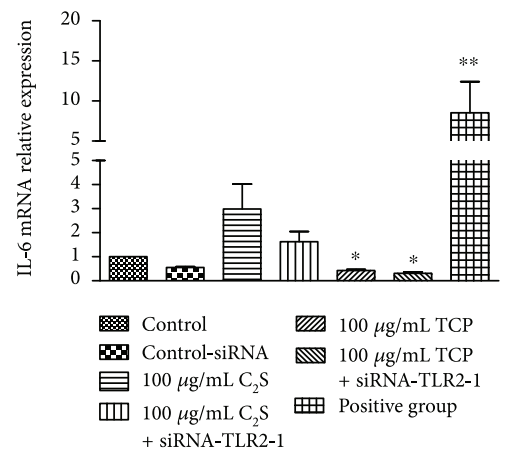

(h)

FIGURE 7: Relative mRNA gene expression. (a) and (b) represent TLR2 expression after being cocultured with $10 \mu \mathrm{g} / \mathrm{mL}$ and $100 \mu \mathrm{g} / \mathrm{mL} \mathrm{C}_{2} \mathrm{~S}$ or TCP for $6 \mathrm{~h}$ and $24 \mathrm{~h}$ in RAW 264.7 cells and the relative TLR2 expression after adding siRNA-TLR2-1. After $24 \mathrm{~h}$, the $\mathrm{C}_{2} \mathrm{~S}$ treatment increased the TLR2 expression more than the TCP treatment compared with the control group. Additionally, the TLR2 mRNA expression in the $10 \mu \mathrm{g} / \mathrm{mL} \mathrm{C}_{2} \mathrm{~S}$ group was significantly higher than the $100 \mu \mathrm{g} / \mathrm{mL}$ TCP group $(P<0.05)$. When we added siRNA-TLR2-1 to these groups, the TLR2 mRNA expression obviously decreased in the $100 \mu \mathrm{g} / \mathrm{mL} \mathrm{C}_{2} \mathrm{~S}(P<0.05), 10 \mu \mathrm{g} / \mathrm{mL} \mathrm{TCP}(P<0.05)$, and $100 \mu \mathrm{g} / \mathrm{mL} \mathrm{TCP}$ groups $(P<0.01)$. (c), (d), (e), (f), (g), and (h) represent the TNF- $\alpha$, IL- $1 \beta$, and IL-6 expressions following coculture with $10 \mu \mathrm{g} / \mathrm{mL}$ and $100 \mu \mathrm{g} / \mathrm{mL}$ of $\mathrm{C}_{2} \mathrm{~S}$ and TCP, respectively, in RAW 264.7 cells after $24 \mathrm{~h}$. The $10 \mu \mathrm{g} / \mathrm{mL} \mathrm{C}_{2} \mathrm{~S}$ treatment increased the TNF- $\alpha$ expression to a greater extent than TCP $(P<0.05)$. After the siRNA-TLR2-1 was added, the expression decreased (e). The $100 \mu \mathrm{g} / \mathrm{mL} \mathrm{C}_{2} \mathrm{~S}$ produced high TNF- $\alpha$ mRNA levels $(P<0.05)$, which were higher than the $100 \mu \mathrm{g} / \mathrm{mL}$ TCP treatment $(P<0.05)(\mathrm{h})$. The TNF- $\alpha$, IL-1 $\beta$, and IL-6 mRNA expression following the $10 \mu \mathrm{g} / \mathrm{mL}$ and $100 \mu \mathrm{g} / \mathrm{mL}$ TCP treatments were even lower than the control group (c, e, f, g, and h). The positive control group produced an obvious increase in TNF- $\alpha$, IL- $1 \beta$, and IL- 6 mRNA expressions. The data are expressed as the mean \pm SD. ${ }^{*} P<0.05,{ }^{* *} P<0.01$, and ${ }^{* * *} P<0.001$ (experimental group versus control). ${ }^{\&} P<0.05, \& \& P<0.01$, and $\& \& \& P<0.001$ (experimental group versus control-siRNA). ${ }^{\#} P<0.05$, ${ }^{\# \#} P<0.01$, and ${ }^{\# \# \# ~} P<0.001$ (between the experimental groups).

for $6 \mathrm{~h}, 24 \mathrm{~h}, 48 \mathrm{~h}$, and $72 \mathrm{~h}$. The $10 \mu \mathrm{g} / \mathrm{mL}$ and $100 \mu \mathrm{g} / \mathrm{mL}$ $\mathrm{C}_{2} \mathrm{~S}$ and TCP particle treatments did not obviously lead to RAW264.7 cell apoptosis after $24 \mathrm{~h}$.

Then, a ROS test kit was used to test the oxidative stress response of $\mathrm{C}_{2} \mathrm{~S}$ and TCP particles in RAW 264.7 cells. ROS play a key role in cell metabolism and survival, as well as in the cytotoxicity mechanisms of various classes of carbon-based nanomaterials $[32,33]$. To verify if the $\mathrm{C}_{2} \mathrm{~S}$ and TCP particles induce an oxidative stress phenomena, DCFH-DA assays were performed [34, 35]. The titanium released from dental implant enhances the preosteoblast adhesion by ROS modulating crucial intracellular pathways 


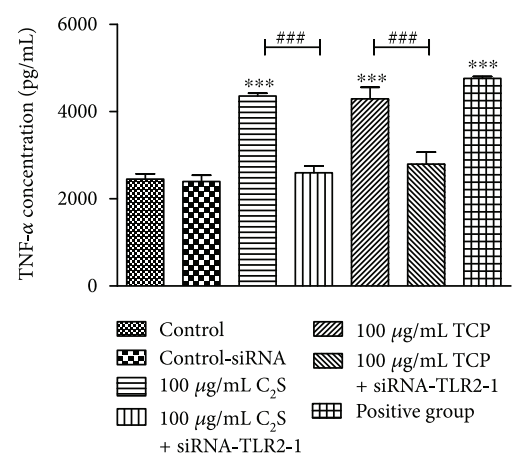

(a)

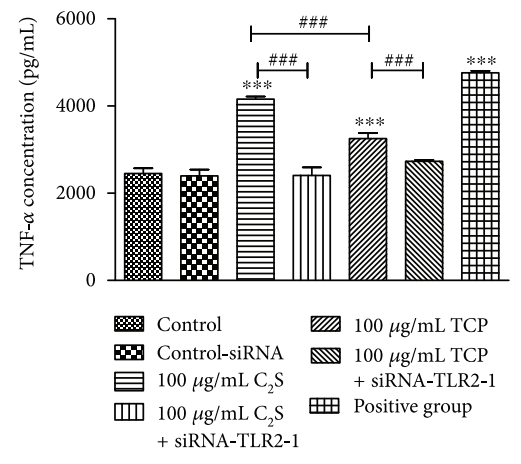

(d)

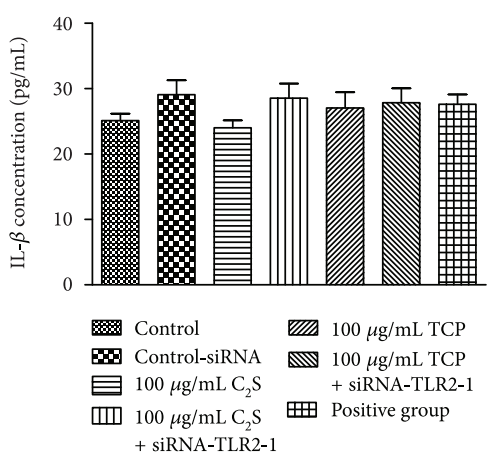

(b)

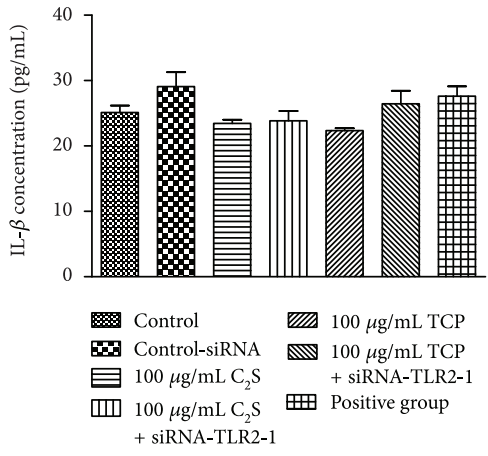

(e)

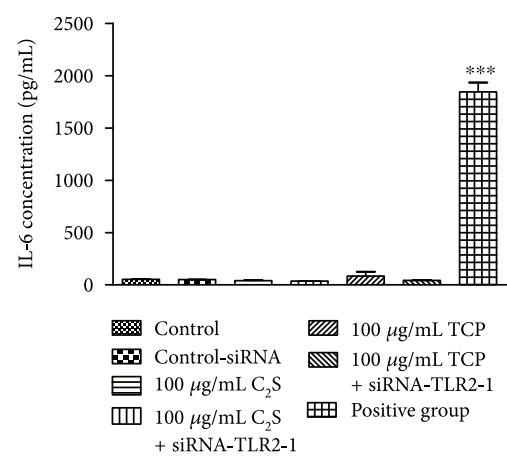

(c)

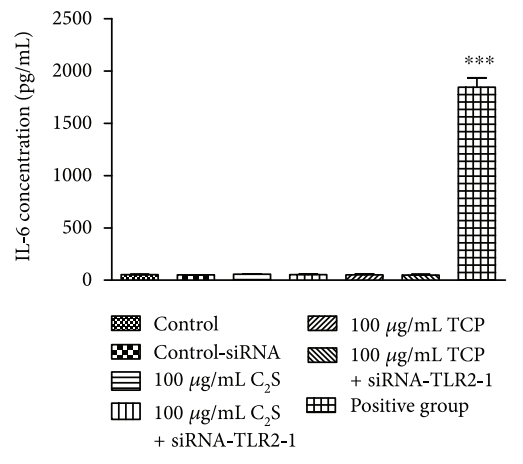

(f)

FIGURE 8: TNF- $\alpha$, IL-1 $\beta$, and IL-6 cytokine concentrations. (a, b, and c) TNF- $\alpha$, IL- $1 \beta$, and IL-6 concentrations of the control group, controlsiRNA group, $10 \mu \mathrm{g} / \mathrm{mL} \mathrm{C}_{2} \mathrm{~S}$ and TCP particle groups, $10 \mu \mathrm{g} / \mathrm{mL} \mathrm{C}_{2} \mathrm{~S}+$ siRNA-TLR2-1 and TCP + siRNA-TLR2-1 groups, and positive control group. ( $\mathrm{d}$, e, and $\mathrm{f}$ ) TNF- $\alpha$, IL- $1 \beta$, and IL- 6 concentrations in the groups mentioned above; however, the material concentration was increased to $100 \mu \mathrm{g} / \mathrm{mL}$. Following incubation for $24 \mathrm{~h}$, the $10 \mu \mathrm{g} / \mathrm{mL}$ and $100 \mu \mathrm{g} / \mathrm{mL} \mathrm{C} \mathrm{S}_{2}$ and TCP particles produced high TNF- $\alpha$ levels $(P<0.001)$; however, when we added siRNA, the levels significantly decreased compared with the non-siRNA treated groups $(P<0.001)$. Moreover, the $100 \mu \mathrm{g} / \mathrm{mL} \mathrm{C}_{2} \mathrm{~S}$ particle group produced more TNF- $\alpha$ than the $100 \mu \mathrm{g} / \mathrm{mL}$ TCP particle group. There were no significant differences in IL- $1 \beta$ and IL-6 concentrations between the experimental groups. The positive control group produced high TNF- $\alpha$ and IL-6 levels $(P<0.001)$.

[36]. Our test demonstrated that high concentrations $(100 \mu \mathrm{g} / \mathrm{mL})$ of $\mathrm{C}_{2} \mathrm{~S}$ and TCP particles produced more ROS than the low concentrations $(10 \mu \mathrm{g} / \mathrm{mL})$. This may imply that we should choose lower concentrations of these two biomaterials when used clinically.

RT-qPCR was used to test the TLR2, TNF- $\alpha$, IL-6, and IL- $1 \beta$ gene expression levels and ELISAs were used to test the production of TNF- $\alpha$, IL- 6 , and IL- $1 \beta$ proinflammatory cytokine levels. We found that $\mathrm{C}_{2} \mathrm{~S}$ particles will exhibit a proinflammatory response by producing TNF- $\alpha$ when cocultured with the murine RAW 264.7 macrophage cell line. At the same time, $\mathrm{C}_{2} \mathrm{~S}$ significantly increased the TLR2 mRNA expression. When we added siRNA-TLR2-1 to the experimental group, the TLR2 and TNF- $\alpha$ mRNA expression levels decreased, which may be a first step to determine that the proinflammatory response mechanism of $\mathrm{C}_{2} \mathrm{~S}$ may be related to TLR2-mediated inflammatory pathways. Next, we determined the relative protein expression and found that the $\mathrm{p}-\mathrm{I} \kappa \mathrm{B}$ and $\mathrm{p}-\mathrm{JNK} 1+\mathrm{JNK} 2+\mathrm{JNK} 3$ expression levels following $100 \mu \mathrm{g} / \mathrm{mL} \mathrm{C}_{2} \mathrm{~S}$ particle exposure increased. Additionally, we also added siRNA-TLR2-1, and the levels remarkably decreased. By chance, we found that the $100 \mu \mathrm{g} / \mathrm{mL}$ TCP particle induced high $\mathrm{p}-\mathrm{I} \kappa \mathrm{B}$ expression levels, which suggests that TCP induces TNF- $\alpha$ through the $\mathrm{p}-\mathrm{I} \kappa \mathrm{B}$ pathway. Then, we continued testing the MyD88 levels and found that there were no significant differences. We have evidence to believe that $\mathrm{C}_{2} \mathrm{~S}$ induces proinflammatory responses through TLR2-mediated NF- $\kappa \mathrm{B}$ and $\mathrm{p}-\mathrm{JNK} 1+\mathrm{JNK} 2+\mathrm{JNK} 3$ pathways in the murine RAW 264.7 macrophage cell line; however, TLR2 might not be the only pathway to induce proinflammatory mediators.

Toll-like receptors (TLRs) are mainly expressed in phagocytes and antigen presenting cells, such as neutrophils, macrophages, and dendritic cells (DCs) [37]. TLRs represent a diverse family of molecules that play a critical role in activating the innate immune system in response to pathogens $[38,39]$. TLR1 and TLR2 are involved in epithelial homeostasis, and a role for TLR6 in increasing intestinal inflammation in response to pathogen-sensing has been observed [40]. A new class of TLR2 ligands that are produced by $P$. gingivalis likely play a significant role in mediating inflammatory responses both at periodontal sites and, potentially, in other tissues where these lipids might accumulate [41]. In this study, we found that the TLR2 expression was high, and we speculate that $\mathrm{C}_{2} \mathrm{~S}$ induces a proinflammatory response. Then, we added siRNA-TLR2-1 to prove it. Moreover, TLR2 plays an important role in the retinal microglial innate response to $S$. aureus, and its sensitization inhibits inflammatory 


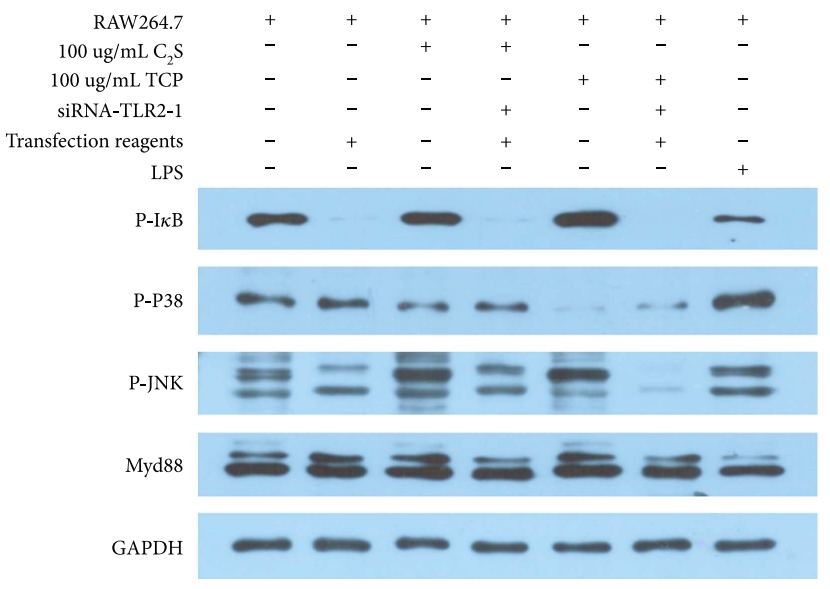

(a)

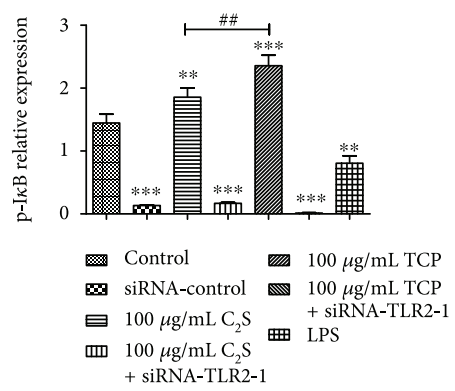

(c)

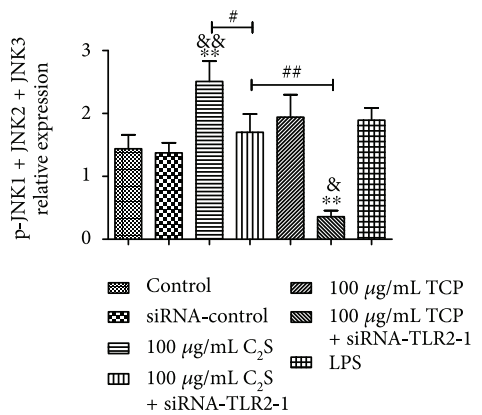

(d)

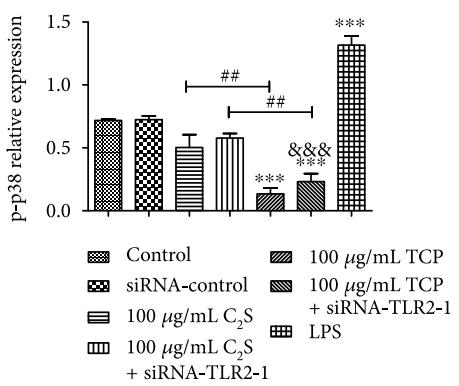

(b)

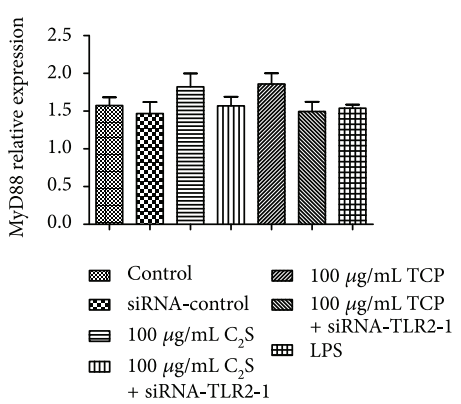

(e)

FIGURE 9: Relative protein expression. (a) represents the specific grouping situation and Western blot result of GAPDH, MyD88, p-p38, $\mathrm{p}-\mathrm{I} \kappa \mathrm{B}$, and p-JNK1 + JNK2 + JNK3. (b), (c), (d), and (e) represent the relative expression of p-p38, p-I $\kappa \mathrm{B}$, and p-JNK1 + JNK2 + JNK3 according to analysis of gray level differences. Compared with the control group, the p-p38 expression levels in the $100 \mu \mathrm{g} / \mathrm{mL} \mathrm{TCP}$ particle group and siRNA-TLR2-1 added group were significant lower $(P<0.001)$, and they showed, respectively, lower levels than the $100 \mu \mathrm{g} / \mathrm{mL} \mathrm{C}_{2} \mathrm{~S}$ particle group with and without siRNA-TLR2-1. The positive control group showed high p-p38 expression levels (b). There was a significant difference in the $\mathrm{p}-\mathrm{I} \kappa \mathrm{B}$ levels between the control and $100 \mu \mathrm{g} / \mathrm{mL} \mathrm{C}_{2} \mathrm{~S}$ particle groups $(P<0.01)$ as well as the TCP particle group $(P<0.001)$. Moreover, an obvious difference was observed between the $100 \mu \mathrm{g} / \mathrm{mL} \mathrm{C}_{2} \mathrm{~S}$ and TCP particle groups $(P<0.01)$. The LPS induced low $\mathrm{p}-\mathrm{I} \kappa \mathrm{B}$ expression levels $(P<0.01)$ (c). The $100 \mu \mathrm{g} / \mathrm{mL} \mathrm{C}_{2} \mathrm{~S}$ particle group expressed high $\mathrm{p}-\mathrm{JNK} 1+\mathrm{JNK} 2+\mathrm{JNK} 3$ expression levels $(P<0.01)$, and they were obviously higher than when siRNA-TLR2-1 was added $(P<0.05)$. However, the $100 \mu \mathrm{g} / \mathrm{mL}$ TCP + siRNA-TLR2-1 group showed low levels of p-JNK1 + JNK2 + JNK3 expression $(P<0.01)$ (d). No significant difference in MyD88 levels was observed in the groups, including in the LPS-treated group (e). The data are expressed as the mean \pm SD. ${ }^{*} P<0.05$, ${ }^{* *} P<0.01$, and ${ }^{* * *} P<0.001$ (experimental group versus control). ${ }^{\#} P<0.05,{ }^{\# \#} P<0.01$, and ${ }^{\# \# \# ~} P<0.001$ (between experimental groups).

response while enhancing phagocytic activity [42]. The adult cognitive behavior can be influenced, in part, by activation or alterations in the TLR2 pathway at birth [43]. It is thus clear that high TLR2 levels may not only represent a proinflammatory response but may also represent an untoward effect, such as influencing cognitive behaviour.

The nuclear factor $\kappa \mathrm{B}(\mathrm{NF}-\kappa \mathrm{B})$ is a nuclear transcription factor that regulates the expression of a large number of genes that are critical for the regulation of apoptosis, viral replication, tumourigenesis, inflammation, and various autoimmune diseases. The activation of $\mathrm{NF}-\kappa \mathrm{B}$ is thought to be part of a stress response as it is activated by a variety of stimuli that include growth factors, cytokines, lymphokines, UV, pharmacological agents, and stress. In its inactive form,
$\mathrm{NF}-\kappa \mathrm{B}$ is sequestered in the cytoplasm, bound by members of the IkB family of inhibitor proteins, which include $\mathrm{I} \kappa \mathrm{B} \alpha$, $\mathrm{I} \kappa \mathrm{B} \beta$, I $\kappa \mathrm{B} \gamma$, and $\mathrm{I} \kappa \mathrm{B} \varepsilon$. The various stimuli that activate $\mathrm{NF}-\kappa \mathrm{B}$ cause $\mathrm{I} \kappa \mathrm{B}$ phosphorylation, which is followed by its ubiquitination and subsequent degradation. NF- $\kappa \mathrm{B}$ was discovered in 1986 by David Baltimore, who worked in the Cancer Research Center of the Massachusetts Institute of Technology in the US, and Ranjan Sen, who worked in the Whitehead Institute for Biomedical Research [44]. NF- $\kappa \mathrm{B}$ plays a critical in regulating function in gene expression by inducing cytokines, and the genes it regulates encode the acute phase response proteins, cytokines, cell adhesion molecules, immunomodulatory molecules, cancer genes, growth factors, and transcription and growth control. By regulating 
the expression of multiple genes, NF- $\kappa \mathrm{B}$ participates in a variety of biological processes, such as immune responses, inflammation, apoptosis, and tumourigenesis.

The C-Jun amino terminal kinase (JNK) family, discovered in 1990, was the observed mitogen-activated protein kinase (MAPK) superfamily member, and it evolutionarily belongs to the conservative serine/threonine protein kinase [45]. The JNK signaling pathway, centered on JNK, can be activated by a variety of factors, such as cytokines, growth factors, and stress (such as ionizing radiation, osmotic pressure, heat shock, and oxidative damage). Many studies suggest that the JNK signaling pathways play an important role in cell differentiation, apoptosis, and stress reactions, and its occurrence and development are involved in a variety of human diseases. Therefore, the JNK signaling pathway is important in regulating the normal and disease status of target cells.

Recent studies found that the MAPK family members (JNK, p38, and ERK) and AP-1 (c-Fos and c-Jun) are well known to be essential to osteoclast formation and proinflammation $[46,47]$. The p-JNK may be related to chronic kidney damage and immunotoxicity $[48,49]$. On the other hand, $\mathrm{NF}-\kappa \mathrm{B}$ and JNK are bound up with ROS [50, 51]. These studies implied that $\mathrm{C}_{2} \mathrm{~S}$ might increase ROS and TNF- $\alpha$ by activating the NF- $\kappa \mathrm{B}$ and JNK pathways.

Wear particles induce periprosthetic inflammation and osteolysis through the activation of NF- $\kappa \mathrm{B}$ [52]. The suppression of chronic inflammation via the inhibition of NF- $\kappa \mathrm{B}$ activity in patients with malfunctioning joint replacements may be an effective strategy to mitigate wear particleinduced periprosthetic osteolysis [53]. Calcium phosphate particles stimulate NF- $\kappa \mathrm{B}$ activity [54]. Moreover, titanium particles induce inflammatory osteolysis through the NF- $\kappa \mathrm{B}$ and JNK pathways [55, 56]. Like the ideal biological material-titanium particles, $\mathrm{C}_{2} \mathrm{~S}$ also induces inflammation. Our study implies that low $\mathrm{C}_{2} \mathrm{~S}$ and TCP particle concentrations may be safer than the high concentrations, and it can further reduce common adverse reactions of ROS and $\mathrm{NF}-\kappa \mathrm{B}$ and JNK pathway activation.

Our study proves that $\mathrm{C}_{2} \mathrm{~S}$ may induce proinflammatory responses through TLR2-mediated NF- $\kappa$ B and JNK pathways in the murine RAW 264.7 macrophage cell line; however, the other definite effects of $\mathrm{C}_{2} \mathrm{~S}$ in RAW 264.7 cells have not been studied, much less the response of $\mathrm{C}_{2} \mathrm{~S}$ in human macrophages. Further studies with $\mathrm{C}_{2} \mathrm{~S}$ should be conducted. This study provides a reference for probing the proinflammatory response mechanism of $\mathrm{C}_{2} \mathrm{~S}$. These findings provide some degree of evidence to support the wide use of $\mathrm{C}_{2} \mathrm{~S}$ in prosthesis, dental implants, and bone substitutes.

\section{Conclusion}

In this study, we demonstrated that $\mathrm{C}_{2} \mathrm{~S}$ particles are not cytotoxic against RAW 264.7 macrophages and that they increase ROS levels. When cocultured with RAW 264.7 cells, $\mathrm{C}_{2} \mathrm{~S}$ particles increased the expression of TLR2 and TNF- $\alpha$. Furthermore, $\mathrm{C}_{2} \mathrm{~S}$ had no obvious influence on IL- $\beta$ and IL-6 expressions. $\mathrm{C}_{2} \mathrm{~S}$ induced its proinflammatory response through TLR2-mediated NF- $\kappa \mathrm{B}$ and JNK pathways in the murine RAW 264.7 macrophage cell line. These results indicate that similar to TCP, $\mathrm{C}_{2} \mathrm{~S}$ might be a safe biomaterial; however, it still produces a potential proinflammatory response. siRNA-TLR2 could decrease proinflammatory responses to some degree. Therefore, these findings provide evidence supporting the choice and widespread use of $\mathrm{C}_{2} \mathrm{~S}$ as a biomaterial for prostheses and dental implants as well as for use with bone substitutes.

\section{Conflicts of Interest}

The authors declare that they have no conflicts of interest.

\section{Authors' Contributions}

Shixiang Lai and Liangjiao Chen contributed equally to this work.

\section{Acknowledgments}

This work was supported by National Natural Science Foundation of China (Grant no. 81600904), Department of Science and Technology of Guangdong Province (Grant no. 2016ZC0147 and 2015110-13), Bureau of Science and Technology and Information Technology, Liwan District, Guangzhou City (Grant no. 20151217094), and Dr. Start-up Fund of Guangzhou Medical University (Grant no. 2015C43). Ministry of Science and Technology in Guangzhou, Liwan District (no. 201704048).

\section{References}

[1] L. Chen, Y. Zhang, J. Liu, L. Wei, B. Song, and L. Shao, "Exposure of the murine RAW 264.7 macrophage cell line to dicalcium silicate coating: assessment of cytotoxicity and proinflammatory effects," Journal of Materials Science: Materials in Medicine, vol. 27, no. 3, p. 59, 2016.

[2] G. W. Groves, "Phase transformations in dicalcium silicate," Journal of Materials Science, vol. 18, no. 6, pp. 1615-1624, 1983.

[3] C. J. Chan, W. M. Kriven, and J. F. Young, "Physical stabilization of the beta gamma transformation in dicalcium silicate," Journal of the American Ceramic Society, vol. 75, no. 6, pp. 1621-11627, 1992.

[4] Z. Gou, J. Chang, and W. Zhai, "Preparation and characterization of novel bioactive dicalcium silicate ceramics," Journal of the European Ceramic Society, vol. 25, no. 9, pp. 1507-1514, 2005.

[5] D. Correa, A. Almirall, R. García-Carrodeguas et al., “ $\beta$ Dicalcium silicate-based cement: synthesis, characterization and in vitro, bioactivity and biocompatibility studies," Journal of Biomedical Materials Research Part A, vol. 102, no. 10, pp. 3693-3703, 2014.

[6] Z. R. Guo, J. Chang, W. Y. Zhai, K. L. Lin, and Y. Zeng, "Study on in vitro bioactivity and cytotoxicity of $\gamma$-Ca2SiO4 Ceramic," Journal of Inorganic Materials, vol. 20, no. 4, pp. 914-920, 2005.

[7] Z. Gou and J. Chang, "Synthesis and in vitro bioactivity of dicalcium silicate powders," Journal of the European Ceramic Society, vol. 24, no. 1, pp. 93-99, 2004. 
[8] X. Liu, Y. Xie, C. Ding, and P. K. Chu, "Early apatite deposition and osteoblast growth on plasma-sprayed dicalcium silicate coating," Journal of Biomedical Materials Research, vol. 74A, no. 3, pp. 356-365, 2005.

[9] P. W. Brown, "Hydration behavior of calcium phosphates is analogous to hydration behavior of calcium silicates," Cement and Concrete Research, vol. 29, no. 8, pp. 1167-1171, 1999.

[10] F. Albee, "Studies in bone growth: triple calcium phosphate as a stimulus to osteogenesis," Annals of Surgery, vol. 71, no. 1, pp. 32-39, 1920.

[11] S. Roy and B. Basu, "Mechanical and tribological characterization of human tooth," Materials Characterization, vol. 59, no. 6, pp. 747-756, 2008.

[12] L. L. Hench, "Bioceramics," Journal of the American Ceramic Society, vol. 81, no. 7, pp. 1705-1728, 1998.

[13] R. Z. LeGeros, "Calcium phosphate materials in restorative dentistry: a review," Advances in Dental Research, vol. 2, no. 1, pp. 164-180, 1988.

[14] S. M. Best, A. E. Porter, E. S. Thian, and J. Huang, "Bioceramics: past, present and for the future," Journal of the European Ceramic Society, vol. 28, no. 7, pp. 1319-1327, 2008.

[15] P. N. De Aza, D. García-Bernal, F. Cragnolini, P. Velasquez, and L. Meseguer-Olmo, "The effects of Ca2SiO4-Ca3(PO4)2 ceramics on adult human mesenchymal stem cell viability, adhesion, proliferation, differentiation and function," Materials Science and Engineering: C, vol. 33, no. 7, pp. 4009-4020, 2013.

[16] J. Sun, L. Wei, X. Liu et al., "Influences of ionic dissolution products of dicalcium silicate coating on osteoblastic proliferation, differentiation and gene expression," Acta Biomaterialia, vol. 5, no. 4, pp. 1284-1293, 2009.

[17] J. Sun, J. Li, X. Liu, L. Wei, G. Wang, and F. Meng, "Proliferation and gene expression of osteoblasts cultured in DMEM containing the ionic products of dicalcium silicate coating," Biomedicine \& Pharmacotherapy, vol. 63, no. 9, pp. 650-657, 2009.

[18] B. C. Wu, C. K. Wei, N. S. Hsueh, and S. J. Ding, "Comparative cell attachment, cytotoxicity and antibacterial activity of radiopaque dicalcium silicate cement and white-coloured mineral trioxide aggregate," International Endodontic Journal, vol. 48, no. 3, pp. 268-276, 2015.

[19] C.-C. Chen, C.-C. Ho, C.-H. David Chen, W.-C. Wang, and S.-J. Ding, "In vitro, bioactivity and biocompatibility of Dicalcium silicate cements for endodontic use," Journal of Endodontics, vol. 35, no. 11, pp. 1554-1557, 2009.

[20] T. Y. Chiang and S. J. Ding, "Physicochemical properties of radiopaque dicalcium silicate cement as a root-end filling material in an acidic environment," International Endodontic Journal, vol. 46, no. 3, pp. 234-241, 2013.

[21] M. M. Radwan, H. K. Abd El-Hamid, and A. F. Mohamed, "Influence of saline solution on hydration behavior of $\beta$ dicalcium silicate in comparison with biphasic calcium phosphate/hydroxyapatite bio-ceramics," Materials Science and Engineering: C, vol. 57, pp. 355-362, 2015.

[22] P. Velasquez, Z. B. Luklinska, L. Meseguer-Olmo et al., “ $\alpha \mathrm{TCP}$ ceramic doped with dicalcium silicate for bone regeneration applications prepared by powder metallurgy method: in vitro and in vivo studies," Journal of Biomedical Materials Research Part A, vol. 101, no. 7, pp. 1943-1954, 2013.

[23] L. Meseguer-Olmo, S. Aznar-Cervantes, P. Mazón, and P. N. De Aza, “"In vitro” behaviour of adult mesenchymal stem cells of human bone marrow origin seeded on a novel bioactive ceramics in the Ca2SiO4-Ca3(PO4)2 system," Journal of Materials Science: Materials in Medicine, vol. 23, no. 12, pp. 3003-3014, 2012.

[24] M. G. Gandolfi, G. Ciapetti, P. Taddei et al., "Apatite formation on bioactive calcium-silicate cements for dentistry affects surface topography and human marrow stromal cells proliferation," Dental Materials, vol. 26, no. 10, pp. 974-992, 2010.

[25] F. Zuleta, A. Murciano, S. Gehrke, J. Maté-Sánchez de Val, J. Calvo-Guirado, and P. De Aza, "A new biphasic Dicalcium silicate bone cement implant," Materials, vol. 10, no. 7, p. 758, 2017.

[26] M. G. Gandolfi, S. N. Shah, R. Feng et al., "Biomimetic calcium-silicate cements support differentiation of human Orofacial Mesenchymal stem cells," Journal of Endodontia, vol. 37, no. 8, pp. 1102-1108, 2011.

[27] P. N. de Aza, F. Zuleta, P. Velasquez, N. Vicente-Salar, and J. A. Reig, " $\alpha$ 'H-Dicalcium silicate bone cement doped with tricalcium phosphate: characterization, bioactivity and biocompatibility," Journal of Materials Science: Materials in Medicine, vol. 25, no. 2, pp. 445-452, 2014.

[28] V. G. Varanasi, E. Saiz, P. M. Loomer et al., "Enhanced osteocalcin expression by osteoblast-like cells (MC3T3-E1) exposed to bioactive coating glass $\left(\mathrm{SiO}_{2}-\mathrm{CaO}-\mathrm{P}_{2} \mathrm{O}_{5}-\mathrm{MgO}-\mathrm{K}_{2} \mathrm{O}-\mathrm{Na}_{2} \mathrm{O}\right.$ system) ions," Acta Biomaterialia, vol. 5, no. 9, pp. 3536-3547, 2009.

[29] J. Li, L. Wei, J. Sun, and G. Guan, "Effect of ionic products of dicalcium silicate coating on osteoblast differentiation and collagen production via TGF- $\beta 1$ pathway," Journal of Biomaterials Applications, vol. 27, no. 5, pp. 595-604, 2011.

[30] Y. Zhang, W. Yn, and Y. Zhao, “A study of tissue engineered periodontal ligament based on human periodontal ligament cells and $\beta$-TCP," Journal of Oral Science Research, vol. 3, pp. 243-245, 2005.

[31] S. Wei, L. Zi-rong, W. Bai-liang et al., "Porous bioceramic beta-tricalcium phosphate combined with bone marrow mesenchymal stem cells in the repair of osteonecrosis of the femoral head model: an ultra structure observation," Journal of Clinical Rehabilitative Tissue Engineenng Research, vol. 03, pp. 457-460, 2009.

[32] Y. Jiang, X. Wang, and D. Hu, "Furanodienone induces G0/G1 arrest and causes apoptosis via the ROS/MAPKs-mediated caspase-dependent pathway in human colorectal cancer cells: a study in vitro and in vivo," Cell Death \& Disease, vol. 8, no. 5, article e2815, 2017.

[33] W. Hu, C. Peng, W. Luo et al., "Graphene-based antibacterial paper," ACS Nano, vol. 4, no. 7, pp. 4317-4323, 2010.

[34] B. Kalyanaraman, V. Darley-Usmar, K. J. A. Davies et al., "Measuring reactive oxygen and nitrogen species with fluorescent probes: challenges and limitations," Free Radical Biology \& Medicine, vol. 52, no. 1, pp. 1-6, 2012.

[35] A. M. Jastrzębska, A. Szuplewska, T. Wojciechowski et al., "In vitro studies on cytotoxicity of delaminated Ti3 C2 MXene," Journal of Hazardous Materials, vol. 339, pp. 1-8, 2017.

[36] M. C. Rossi, F. J. B. Bezerra, R. A. Silva et al., "Titaniumreleased from dental implant enhances pre-osteoblast adhesion by ROS modulating crucial intracellular pathways," Journal of Biomedical Materials Research Part A, vol. 105, no. 11, pp. 2968-2976, 2017.

[37] D. Liu and J. E. Uzonna, "The early interaction of Leishmania with macrophages and dendritic cells and its influence on the 
host immune response," Frontiers in Cellular and Infection Microbiology, vol. 2, 2012.

[38] R. Medzhitov, "Toll-like receptors and innate immunity," Nature Reviews Immunology, vol. 1, no. 2, pp. 135-145, 2001.

[39] R. Medzhitov, P. Preston-Hurlburt, and C. A. Janeway, "A human homologue of the Drosophila toll protein signals activation of adaptive immunity," Nature, vol. 388, no. 6640, pp. 394-397, 1997.

[40] L. Choteau, H. Vancraeyneste, D. Le Roy et al., "Role of TLR1, TLR2 and TLR6 in the modulation of intestinal inflammation and Candida albicans elimination," Gut Pathogens, vol. 9, no. 1, p. 9, 2017.

[41] R. B. Clark, J. L. Cervantes, M. W. Maciejewski et al., "Serine lipids of Porphyromonas gingivalis are human and mouse toll-like receptor 2 ligands," Infection and Immunity, vol. 81, no. 9, pp. 3479-3489, 2013.

[42] T. Kochan, A. Singla, J. Tosi, and A. Kumar, "Toll-like receptor 2 ligand pretreatment attenuates retinal microglial inflammatory response but enhances phagocytic activity toward Staphylococcus aureus," Infection and Immunity, vol. 80, no. 6, pp. 2076-2088, 2012.

[43] R. Madar, A. Rotter, H. W. Ben-Asher et al., "Postnatal TLR2 activation impairs learning and memory in adulthood," Brain, Behavior, and Immunity, vol. 48, pp. 301-312, 2015.

[44] R. Sen and D. Baltimore, "Inducibility of $\kappa$ immunoglobulin enhancer-binding protein NF- $\kappa \mathrm{B}$ by a posttranslational mechanism," Cell, vol. 47, no. 6, pp. 921-928, 1986.

[45] M. Hibi, A. Lin, T. Smeal, A. Minden, and M. Karin, "Identification of an oncoprotein- and UV-responsive protein kinase that binds and potentiates the c-Jun activation domain," Genes \& Development, vol. 7, no. 11, pp. 2135-2148, 1993.

[46] S. X. Sun, H. H. Guo, J. Zhang, B. Yu, K. N. Sun, and Q. H. Jin, "BMP-2 and titanium particles synergistically activate osteoclast formation," Brazilian Journal of Medical and Biological Research, vol. 47, no. 6, pp. 461-469, 2014.

[47] H. Yamada, T. Umemoto, M. Kakei et al., "Eicosapentaenoic acid shows anti-inflammatory effect via GPR120 in 3T3-L1 adipocytes and attenuates adipose tissue inflammation in diet-induced obese mice," Nutrition \& Metabolism, vol. 14, no. 1, p. 33, 2017.

[48] M. R. Afrin, S. Arumugam, M. A. Rahman et al., "Curcumin reduces the risk of chronic kidney damage in mice with nonalcoholic steatohepatitis by modulating endoplasmic reticulum stress and MAPK signaling," International Immunopharmacology, vol. 49, pp. 161-167, 2017.

[49] S. Dhani, S. Nagiah, D. B. Naidoo, and A. A. Chuturgoon, "Fusaric acid immunotoxicity and MAPK activation in normal peripheral blood mononuclear cells and Thp-1 cells," Scientific Reports, vol. 7, no. 1, p. 3051, 2017.

[50] A. A. Fouad and I. Jresat, "Hepatoprotective effect of coenzyme Q10 in rats with acetaminophen toxicity," Environmental Toxicology and Pharmacology, vol. 33, no. 2, pp. 158-167, 2012.

[51] H. W. Zimmermann, C. Trautwein, and F. Tacke, "Functional role of monocytes and macrophages for the inflammatory response in acute liver injury," Frontiers in Physiology, vol. 3, 2012.

[52] T. Sato, J. Pajarinen, T. Lin et al., "NF- $\kappa$ B decoy oligodeoxynucleotide inhibits wear particle-induced inflammation in a murine calvarial model," Journal of Biomedical Materials Research Part A, vol. 103, no. 12, pp. 3872-3878, 2015.
[53] T. Lin, Y. Tamaki, J. Pajarinen et al., "Chronic inflammation in biomaterial induced periprosthetic osteolysis: NF- $\kappa \mathrm{B}$ as a therapeutic target," Acta Biomaterialia, vol. 10, no. 1, pp. 110, 2014.

[54] Y. Sakai, E. Nemoto, S. Kanaya, M. Shimonishi, and H. Shimauchi, "Calcium phosphate particles induce interleukin-8 expression in a human gingival epithelial cell line via the nuclear factor- $\kappa \mathrm{B}$ signaling pathway," Journal of Periodontology, vol. 85, no. 10, pp. 1464-1473, 2014.

[55] Y. P. Zhao, J. L. Wei, Q. Y. Tian et al., "Progranulin suppresses titanium particle induced inflammatory osteolysis by targeting TNF $\alpha$ signaling," Scientific Reports, vol. 6, no. 1, article 20909, 2016.

[56] S. Jin, J. Y. Park, J. M. Hong et al., "Inhibitory effect of (-)-epigallocatechin gallate on titanium particle-induced TNF- $\alpha$ release and in vivo osteolysis," Experimental \& Molecular Medicine, vol. 43, no. 7, pp. 411-418, 2011. 


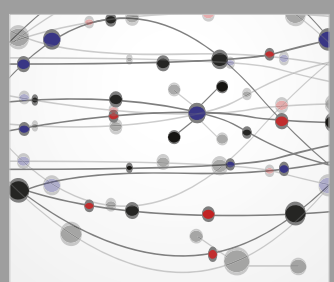

The Scientific World Journal
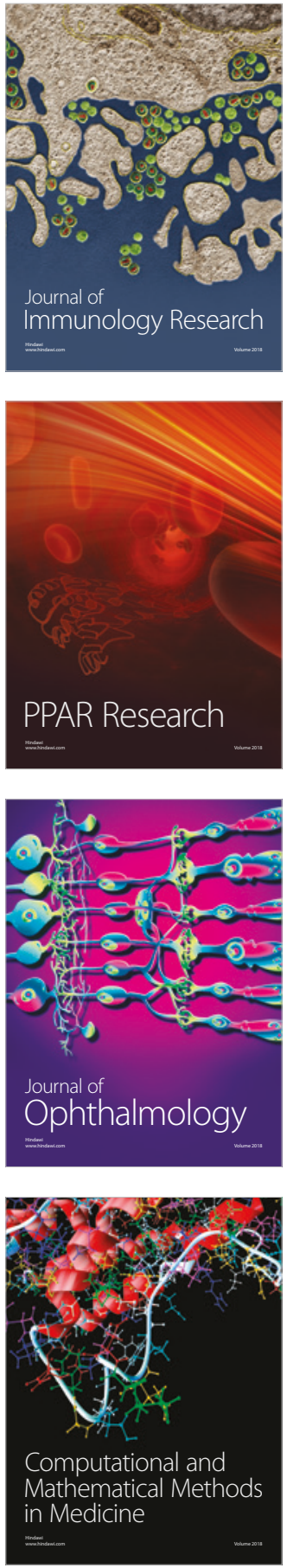

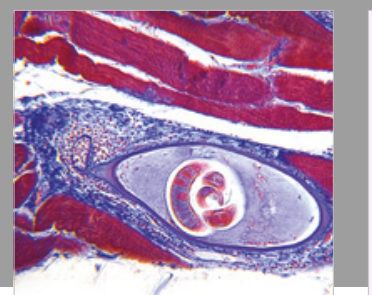

Gastroenterology Research and Practice

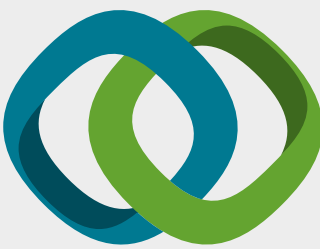

\section{Hindawi}

Submit your manuscripts at

www.hindawi.com
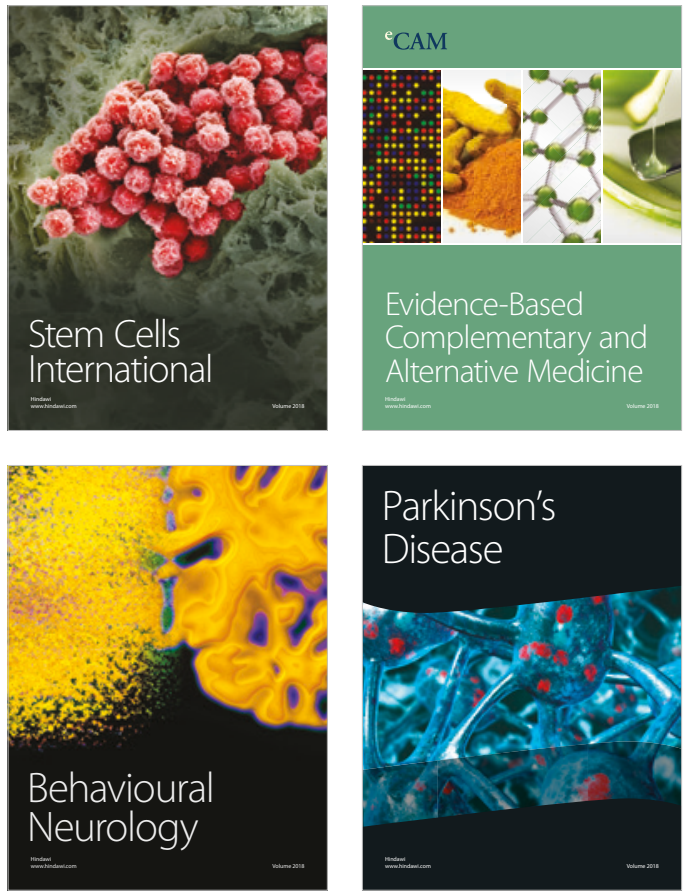

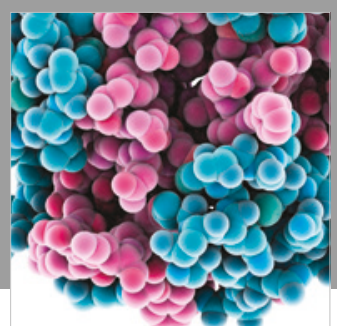

ournal of

Diabetes Research

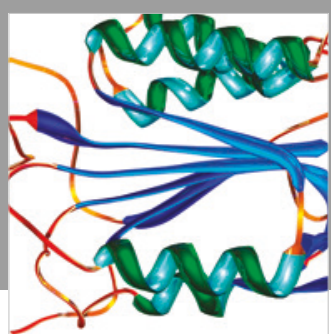

Disease Markers
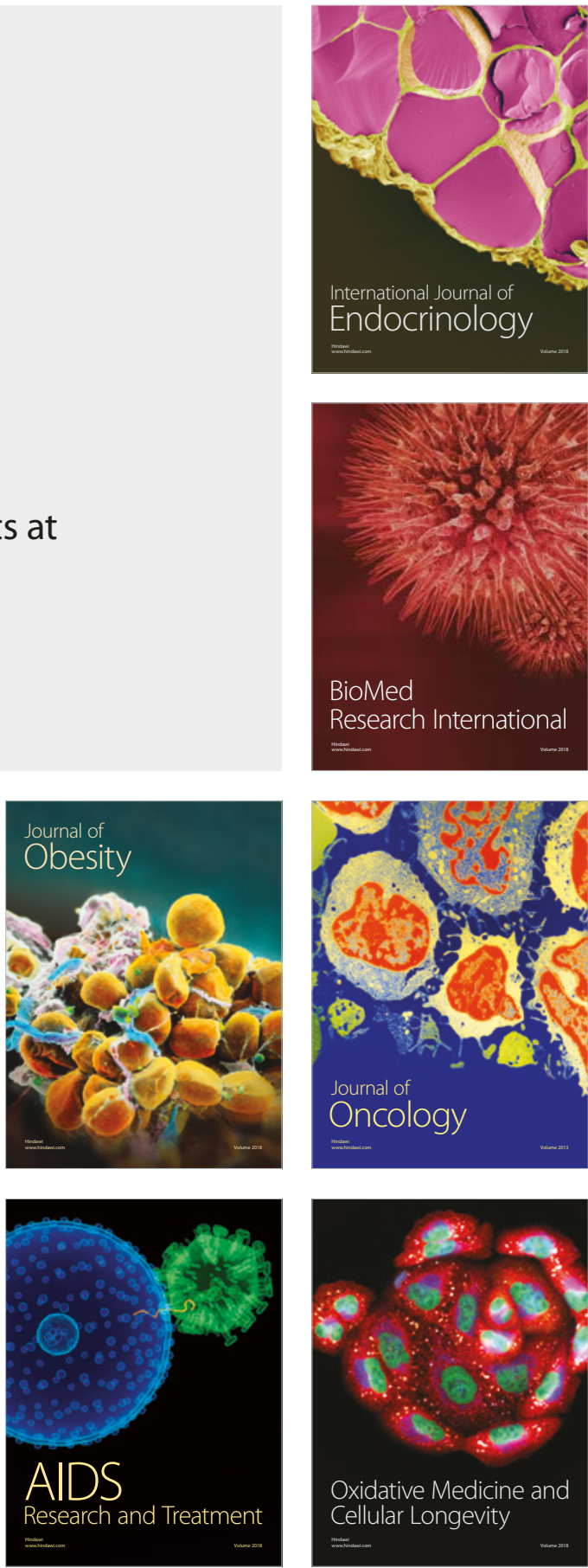